\title{
Bail-in from an Insolvency Law Perspective
}

By Lynette Janssen* | Norton Journal of Bankruptcy Law and Practice

\section{Search Details}

Jurisdiction: Federal

\section{Delivery Details}

Date: $\quad$ October 11, 2017 at 6:34 AM

Delivered By:

Client ID:

WLN 
26 No. 5 J. Bankr. L. \& Prac. NL Art. 3

Norton Journal of Bankruptcy Law and Practice | October 2017

Volume 26, Issue 5

Norton Journal of Bankruptcy Law and Practice

By Lynette Janssen*

Bail-in from an Insolvency Law Perspective

This article will also appear in a forthcoming issue of the Journal of International Banking Law and Regulation.

\begin{abstract}
$\underline{\text { Abstract }}$
The BRRD and the SRM Regulation established a bank resolution framework that interacts with rather than replaces more general rules of national insolvency law. Policy and academic discussions recognise a need for further alignment of national insolvency laws across the EU with the existing bank resolution framework but at the same time doubts exist whether a full-fledged harmonisation of insolvency law is feasible. Using the legal theory of coherence in a legal system, this article analyses to what extent the bailin rules are already aligned with and how they are embedded into more general areas of Dutch private law, in particular insolvency law. It shows that with regard to specific aspects of the interaction between the bail-in rules and Dutch private law amendment or clarification is needed to avoid uncertainties about the application of bail-in and related safeguards for shareholders and creditors. These observations might be valid for other EU Member States as well.
\end{abstract}

\title{
Table of contents
}

1. Introduction

2. Conceptual aspects of bail-in from a regulatory and insolvency law perspective

\subsection{Bail-in from a regulatory perspective}

2.2 Bail-in from an insolvency law perspective

3. Bail-in as codified in the BRRD and the SRM Regulation

4. Coherence in the national legal system

4.1 Alignment with certain principles and policy goals of insolvency law

4.1.1 Principles of insolvency law in the bank resolution framework 4.1.2 Developments towards financial restructuring outside traditional full-fledged (bank) insolvency procedures 4.2 Some technicalities and effects of bail-in that require further alignment with national private law

4.2.1 Effects debt write-down

4.2.2 Effects conversion of claims

5. Conclusion

4.2.3 The hierarchy of claims in bail-in

\section{Introduction}

One of the key lessons of the recent financial crisis for policymakers within the European Union ('EU') was that the existing bank (credit institution) ${ }^{1}$ insolvency rules needed to be drastically amended. It was generally felt that the fact that a fully harmonised bank-specific insolvency framework did not exist within the EU stood in sharp contrast with the increased international activities and interconnectedness of the 
European banking sector. ${ }^{2}$ Moreover, in most Member States the bank insolvency regime was broadly similar to the ordinary corporate insolvency regime, if special bank insolvency rules did exist at al. ${ }^{3}$ Where early intervention measures had been proven insufficient to restore a bank's financial viability, under the applicable insolvency laws the failing bank would generally be subject to a reorganisation or liquidation procedure in which courts were typically attributed an important role. ${ }^{4}$ The fact that during the financial crisis authorities decided to bail-out several failing banks with taxpayers' money because the opening of such a formal insolvency procedure ${ }^{5}$ in respect of these banks could have undesirable effects, has been argued to clash with the idea that the failure of a company, including a bank, needs to be dealt with by insolvency law. ${ }^{6}$ Conceptually, insolvency law fulfils — so the argument runs — a crucial and necessary role in market economies because it determines the consequences of commercial and financial failure and follows clear priority rules, while the management and shareholders are not spared from the consequences of risky decisions. ${ }^{7}$

Against this background, the bank resolution rules that have recently been introduced at EU level seek to find a compromise between objectives that have often been presented as being at different ends of the spectrum. ${ }^{8}$ These include on the one hand the objectives of ensuring the continuity of critical functions of a failing bank as well as financial stability, and on the other hand the objectives to limit the implicit guarantee that a bank will always be rescued with public (taxpayers') money and incentivise shareholders and creditors to become more alert about the bank's risk-taking. ${ }^{9}$ The former are likely to be pursued in case of a guarantee by a government of all debts, while liquidation under the applicable insolvency laws may have a favourable effect on market discipline. ${ }^{10}$ The EU bank resolution rules aim to replicate the economic effects of a traditional insolvency procedure for a failing bank's shareholders and creditors and recognise several principles of insolvency law, while the effects of a bank failure on the financial system and the wider economy are taken into account. ${ }^{11}$ They establish an administrative, non-judicial bank resolution procedure in which a resolution authority is allowed to intervene in and restructure a bank which is considered failing or likely to fail, with a view to safeguard its essential services and functions, including its deposit portfolio, and make other parts subject to a controlled wind-down. ${ }^{12}$ The rules can be found in the Bank Recovery and Resolution Directive ${ }^{13}$ ('BRRD') and the Single Resolution Mechanism Regulation ${ }^{14}$ ('SRM Regulation'). ${ }^{15}$ The former, which applies to the EU as a whole and had to be implemented in national law before 1 January 2015, provides for a harmonised set of rules on the resolution of failing banks, investment firms and certain other financial institutions at Member State level as well as the cooperation between national authorities. ${ }^{16}$ Under the latter, a new agency in Brussels, Belgium, i.e. the Single Resolution Board, applies many of the BRRD's resolution rules - to a large extent since 1 January 2016 - in a unified and centralised resolution procedure for the larger and cross-border operating banks in the nineteen EU Member States that form the Euro Area. ${ }^{17}$

\section{Bank resolution rules and their interaction with more general areas of national private law}

Literature presents the new bank resolution regime and more general insolvency law often as distinct disciplines and a bank resolution procedure under the BRRD and SRM Regulation is portrayed as an alternative to a formal insolvency procedure. ${ }^{18}$ Indeed, looking at the public interests involved in a bank failure, as regards most banks the application of the new resolution tools and powers is likely to be the preferred course of action rather than the commencement of a liquidation procedure ${ }^{19}$ for the failing bank as a whole. Yet, the distinction between the bank resolution rules and general insolvency law becomes less clear once 'insolvency' is regarded as a broad concept and umbrella term that does not necessarily require 
that the traditional requirements of balance sheet or cash flow insolvency are met but is in relation to a bank dependent on the assessment of supervisory and resolution authorities whether it is for instance sufficiently capitalised to be allowed to continue operating. ${ }^{20}$ As noted above, the ultimate objectives of the bank resolution rules are to a certain extent different than the traditional objectives of more general insolvency law. Yet, most of their underlying principles are principles of insolvency law. ${ }^{21}$ Moreover, although insolvency lawyers may be unknown with some specific terms that are used by the bank resolution rules, ${ }^{22}$ a bank resolution procedure can have elements of both reorganisation and liquidation. ${ }^{23}$ As will be examined below, substantial legislative changes to general corporate insolvency law have been made or have been proposed in EU Member States to supplement traditional liquidation procedures with a procedure that is directed towards some form of reorganisation or restructuring. ${ }^{24}$ Both more general insolvency law in many jurisdictions and the bank resolution rules focus now on the prevention or streamlining of a debtor's insolvency. ${ }^{25}$ In general, it seems preferable to classify bank resolution law as a special part of insolvency law in a jurisdiction. ${ }^{26}$

While literature also discusses the bank resolution rules often from a regulatory and banking supervisory perspective, ${ }^{27}$ the rules rely heavily on more general rules of private law for their interpretation and application. ${ }^{28}$ For instance, the BRRD and SRM Regulation explicitly refer to national private law, and especially more general insolvency law. They provide, inter alia, that a failing bank should only be subject to a resolution procedure if the bank cannot be liquidated under insolvency law, ${ }^{29}$ while the application of bail-in is required to follow to a certain extent the ranking of claims recognised under national insolvency law. ${ }^{30}$ Even in cases for which these references are not explicitly made at EU level, the bank resolution rules are expected to interact directly with more general areas of private law at national level. For example, according to the Dutch resolution authority, De Nederlandsche Bank ('DNB'), a writedown and cancellation of a bank's existing shares in the application of the bail-in mechanism requires the immediate issuance of new shares because under Dutch company law a public limited company (Naamloze Vennootschap) must have shareholders at all times. ${ }^{31}$

The special position of banks in EU insolvency legislation has received attention before. Since its introduction sixteen years ago, the Winding-up Directive, ${ }^{32}$ which is mainly a private international law instrument rather than an instrument to harmonise substantive bank insolvency law, has been subject to a debate on its relationship with another EU legislative instrument in the field of cross-border insolvency, i.e. the Insolvency Regulation. ${ }^{33}$ Some authors have argued that the rules of this directive and regulation are part of a consistent statutory scheme and 'all form the "hermeneutic circle" within which the interpretations should be made', ${ }^{34}$ while others have emphasised the special nature of the principles and norms governing bank failures. ${ }^{35}$ Yet, consensus seems to exist that the EU legislature has an important task in safeguarding the coherence of the EU system of insolvency law, including the alignment of the Winding-up Directive with the Insolvency Regulation and vice versa. ${ }^{36}$

The BRRD and SRM Regulation are now subject to a debate that focuses on the interplay between the harmonised bank resolution rules and more general areas of national private law, including national substantive insolvency law. For several scholars, the desirable picture of a bank resolution framework has been one with consistently implemented and clear rules, a clearly defined priority of claims and a consistent overall resolution policy. ${ }^{37}$ This view seems to be in line with the European legislature's recent efforts to build a Single Resolution Mechanism ('SRM') to avoid substantial discrepancies in the application of bank resolution rules and policies across participating EU Member States. ${ }^{38}$ At the moment, however, it 
is recognised in academic as well as policy discussions that within the EU (and especially within the SRM participating Member States) there is a need for a further alignment of national insolvency law, in particular the insolvency order of priority of claims, with the existing bank resolution framework. ${ }^{39}$ It is believed that differences that currently exist between Member States' insolvency laws as well as between these laws and the applicable resolution framework may, inter alia, negatively affect the predictability of and trust in the application of bank resolution tools, for instance of creditors who wish to assess the likelihood that their claims are written down or converted by authorities. These uncertainties about the possible applications of those tools and related 'safeguards' for investors may also cause a higher risk of legal challenges. ${ }^{40}$ Yet, at the same time, it is argued that a full-fledged harmonisation of insolvency law at EU level may not be possible, particularly because it is closely connected to and intertwined with many other areas of national law, including property, contract and company law, and reflects national regulatory traditions. ${ }^{41}$ An analysis to what extent the SRM Regulation's and BRRD's bank resolution rules, principles and objectives are currently already aligned with and how they are now embedded into insolvency law — and even broader: several more general areas of private law - at national level can therefore be of relevance in discussions about the way in which the development and harmonisation of the bank insolvency framework can best be achieved. Yet, such an analysis has not yet received the attention which it deserves.

\section{A coherent system of law}

This article is aimed at analysing several relationships between the rules on the most discussed resolution mechanism available for resolution authorities, which is the bail-in mechanism, and more general areas of national private law from a legal theoretical perspective. It asks the question to what extent these relationships can be considered coherent relationships. ${ }^{42}$ The bail-in mechanism is in legal literature considered the 'innovative Herzstück', 43 'Wunderwaffe', 44 'most controversial weapon among the guns ${ }^{45}$ and 'the most significant regulatory achievement in post-crisis efforts to end "Too Big To Fail", 46 It allows authorities to reduce the nominal value of share capital, write-down liabilities and convert liabilities into share capital of a bank. While this article's analysis also requires an examination of the bail-in rules as established at EU level, the focus of the assessment in the paragraphs below is how the bail-in rules, principles and objectives provided by the SRM Regulation, which is by its nature directly applicable at national level, and the BRRD, as implemented into national law, have found a way to for example adjust to or exist along with existing legal components of more general areas of national private law. ${ }^{47}$ Thus, the study focuses in particular on the issue of coherence at a horizontal, national level, which issue has been considered of importance in the context of rules and legal concepts deriving from EU legislative instruments as they typically only deal with very specific issues and often deviate from terminology and interpretations traditionally used at national law. ${ }^{48}$ Moreover, it mainly draws on Dutch law, but the analysis is expected to be relevant for other EU Member States than the Netherlands as well. The study made in this contribution can serve as a basis for other projects assessing — provided that EU competence exists — what should be included in any EU harmonisation instrument to improve the national relationships, which would especially deal with the relationship between EU law and more general areas of national law, i.e. a matter of so-called 'diagonal coherence'. 49

Although the concept of legal coherence in the field of private law is ascribed a variety of different meanings in literature, ${ }^{50}$ here it focuses on the elements that form a system of law and it is considered to serve important goals such as legal certainty and predictability. ${ }^{51}$ At the surface level of the legal system, coherence requires that the legal components such as principles, rules and cases allow non-contradictory interpretations and definitions and are logically connected with each other. Moreover, at a deeper level, it requires a set with some common policy goals and objectives. ${ }^{52}$ Yet, it should not always be considered 
equivalent to uniformity. If, for instance, different definitions of a concept or term used in two areas of law is preferable, for the sake of legal certainty it may be necessary to explicitly provide how the two definitions relate to each other. ${ }^{53}$

The analysis is structured as follows. Paragraph 2 briefly examines conceptual aspects of bail-in from an often used perspective, which is a mere regulatory and banking supervisory perspective, as well as from an insolvency law perspective. Paragraph 3 discusses the application of the bail-in mechanism under the BRRD and the SRM Regulation. The coherence analysis in the next paragraph (paragraph 4) will be made for selected examples of relationships, which - according to the present author - represent important relationships between the bail-in rules and more general areas of national private law in view of the application and interpretation of the rules. The first section (paragraph 4.1) highlights two types of relationships between Dutch general insolvency law and bank resolution law that should not be considered problematic taking into account the concept of coherence. Paragraph 4.2 then analyses three aspects of the application of the bail-in mechanism (the effects of a debt write-down, the effects of conversion of claims and the hierarchy of claims in bail-in) to illustrate that national or EU legislative action can be argued necessary to fit bank resolution law better into existing Dutch private law or vice versa. Paragraph 5 concludes and summarises the main points of this article. It is worth noting that although the BRRD and the SRM Regulation make a distinction between two types of tools for effecting the write-down and conversion powers, i.e. the write-down and conversion of capital instruments tool and the bail-in tool, ${ }^{54}$ the tools are here together referred to as 'bail-in mechanism' and their application 'bail-in'. In addition, notwithstanding the fact that not all Dutch banks are organised as a public limited company, this article focuses on this type of company.

\section{Conceptual aspects of bail-in from a regulatory and insolvency law perspective}

\subsection{Bail-in from a regulatory perspective}

The function of the share capital any stock company holds to ensure that it can continue its activities in the foreseeable future has been deemed threefold. The capital, which is provided by the shareholders who benefit if the company is able to pay dividends but are in insolvency generally only paid after all other company's creditors, ensures that the company is able to finance its daily activities. In addition, it serves as a basis for apportioning each shareholder a share in the control over the company. Thirdly, for the company's creditors it forms a 'buffer' and guarantee that the company can fulfil its commitments to a certain extent. ${ }^{55}$ In contrast to many other companies, banks are required to hold an adequate level of regulatory capital that is composed of a layer of share capital as well as a mix of subordinated debt and hybrid capital. ${ }^{56}$ In theory a thick layer of regulatory capital could ensure that in a formal insolvency procedure a bank's losses are shouldered by shareholders and investors in subordinated debt rather than the bank's depositors and the wider economy. Outside a formal insolvency procedure, however, the mere subordination of debt may not provide any help in absorbing unexpected losses. ${ }^{57}$ For a non-financial corporate debtor an agreement with its creditors on a reduction of the nominal value of debt, i.e. a haircut, and/or a conversion of (a part of) the outstanding debt into one or more classes of share capital, may be a solution if the shareholders are not willing to invest additional capital and the company is in a troubled state. Yet, for a bank a private workout may not be feasible if the shareholders and creditors are not willing to cooperate and a solution needs to be found within a very short period of time. ${ }^{58}$ Accordingly, the last several years an important aspect of the regulatory reforms in the EU was to restrict the instruments that qualify as regulatory capital to a large extent to those that have a so-called loss absorbing capacity much earlier than the moment the bank would be balance-sheet insolvent, i.e. it would not have enough assets to pay all debts. ${ }^{59}$ Contingent capital instruments, which include contingent convertible bonds ('CoCos') and write-down bonds, acquired 
increasing support from banks and from regulators, economist and academics on a national as well as global level. ${ }^{60}$ These instruments' terms and conditions have a clause which generally provides that they are written down or converted into common shares or preference shares when a predetermined trigger event occurs. ${ }^{61}$ Under the Capital Requirements Regulation ${ }^{62}$ ('CRR') capital instruments may only count as Additional Tier 1 ('AT1') instruments if the instruments have a capacity to absorb losses at a trigger point that relates to a bank's Common Equity Tier 1 ('CET1') capital ratio. ${ }^{63}$

Against this background, a statutory bail-in mechanism has been considered a supplement to the contingent capital instruments issued by banks. ${ }^{64}$ While the latter are generally triggered if the issuing bank's operations are still considered going concern, the former may be applied in a wider range of circumstances, depending on the exercise of discretion by the resolution authority rather than a contractually agreed trigger event. ${ }^{65}$ In practice, the trigger of the application of the contingent capital instruments may not always precede the application of the bail-in mechanism. A bank's capital providers may even first experience that the contractual trigger event has occurred and that their instruments are converted into shares, and subsequently be subject to a statutory bail-in. ${ }^{66}$ A significant amount of literature exists examining the role and goals of bail-in. According to some authors, bail-in is based on a principle of 'private penalty' or 'private insurance' as it seeks to ensure that bank losses are imposed on the persons who provide the bank's regulatory capital. ${ }^{67}$ Moreover, it has been argued that the concept aims to facilitate a swift reorganisation of a failing bank's balance sheet, ${ }^{68}$ while others have stated that it may not only be of relevance if a bank has solvency problems but it can also fulfil an important role in overcoming panic in the markets and run risks at an earlier stage. ${ }^{69}$ While shareholders are granted economic rights as well as control and governance rights and are traditionally the first the bear losses up to the amount of their investments, a bank's investors in subordinated debt instruments are typically only granted contractual rights but now also run the risk to be called at an early stage to shoulder the bank's losses and to lose their investments. It has been submitted that this development requires the reform of company law to ensure that both the bank's shareholders as well as the bondholder and other debt holders are entitled to participate in the decision-making procedures and are able to control and monitor the management of the bank. ${ }^{70}$ Yet according to others, granting bondholders voting rights would not contribute to achieving relevant objectives such as preventing the bank's insolvency and overcoming shareholder pressure on management to accept high levels of risks. ${ }^{71}$

\subsection{Bail-in from an insolvency law perspective}

From a mere insolvency law perspective, ${ }^{72}$ a statutory bail-in mechanism to be applied by administrative authorities creates a special type of debt restructuring procedure for banks. The concept of bail-in may remind insolvency lawyers of the so-called 'chameleon equity firm', which was proposed by Adler many years ago. ${ }^{73}$ In brief, this company would issue debt in several tranches and when it would show signs of financial distress the claims in the high-priority classes are retained but only to the extent these obligations can be fulfilled. The claims with the highest priority ranking that cannot be paid are automatically converted into equity, whereas the remaining lower-priority tranches, including the original equity class, are automatically wiped out, as was contractually specified. In this way, the firm is able to continue its operations with the lower-priority creditors having control over the firm. ${ }^{74}$ In a similar form, the application of a bail-in mechanism replicates a debt restructuring procedure governed by general company and insolvency law in which the nominal value of the share capital and claims against the company is reduced and creditors' claims are converted into equity interests in the company's capital. ${ }^{75}$ Creditors may receive shares in the company or warrants or other options to subscribe for shares in the company's capital in exchange for a cancellation of their claims. ${ }^{76}$ As is generally the case in a debt-to-equity swap under 
company or insolvency law, the aim of the application of the bail-in mechanism may be the recapitalisation of either the existing company or a new entity that receives assets and liabilities of the existing company. ${ }^{77}$

Moreover, the bail-in rules create a kind of pre-packaged procedure in the sense that the debt restructuring is based on the resolution strategy agreed by the relevant resolution authorities beforehand in so-called resolution plans. ${ }^{78}$ To be sure, while under insolvency law the decision whether a company is liquidated or reorganised traditionally depends on the question in which way the most proceeds are generated for the creditors, ${ }^{79}$ the decision whether a bank should be placed under resolution rather than liquidated as well as which measures are taken is especially dependent on the assessment of the public interests involved. ${ }^{80}$ At that stage a resolution authority is allowed to implement a bail-in even if the shareholders and creditors would not have agreed with the measures. Such a 'cram down' by administrative decision can, according to several scholars, be justified taking into account famous insolvency law theories, including the theory on anti-commons behaviour. In short, it is believed that a failing bank's shareholders and creditors would withhold their consent to any proposed composition or reorganisation plan if they expect a possible rescue of the bank by the government, in which case they think to be better off than in a liquidation of the bank's assets. ${ }^{81}$ Needless to say, this does not mean that a private sector recapitalisation effort cannot be launched before a bank resolution procedure is opened by asking shareholders and creditors to consent to a debtto-equity swap. ${ }^{82}$

\section{Bail-in as codified in the BRRD and the SRM Regulation}

Drawing heavily on the standards and principles of international standard-setters, ${ }^{83}$ in the EU, like in countries such as the United States, ${ }^{84}$ in its wide-scale overhaul of the supervisory and regulatory framework since the most recent global financial crisis considerable attention has been paid to the expansion

of the tools and powers available for authorities to orderly resolve a failing bank. ${ }^{85}$ The SRM is one of the results of the efforts made to establish a comprehensive and further harmonised bank insolvency regime and is the second pillar of the Euro Area's Banking Union, in which the European Central Bank's centralised banking supervision within the Single Supervisory Mechanism ('SSM') constitutes the first pillar. ${ }^{86}$ In contrast to the BRRD, which, as it is a directive, empowers the national legislatures of all EU Member States to transpose its rules into national law and allows a certain amount of discretion to national authorities in the application of the resolution tools and powers, ${ }^{87}$ the SRM Regulation has direct legal effect. It builds on the resolution framework created by the BRRD, which rules are also applied in EU Member States that are not part of the Banking Union. Under the SRM Regulation the Single Resolution Board adopts all decisions relating to the resolution of large and cross-border operating banks, ${ }^{88}$ which are then implemented by the relevant resolution authorities at national level based on national law transposing the BRRD and may be supported by the Single Resolution Fund. ${ }^{89}$

The BRRD requires Member States to designate a public administrative authority that performs all resolution functions and tasks and closely cooperates with, inter alia, the relevant supervisory authorities. ${ }^{90}$ In many Member States, including the Netherlands, the national banking supervisory authority is the designated resolution authority. ${ }^{91}$ According to the resolution rules, the supervisory authority and the resolution authority, which are in the Euro Area, depending on the size of the bank, either the authorities at European level or at national level, ${ }^{92}$ in principle decide together that all three the conditions for resolution are met, i.e. a bank is considered failing or likely to fail, the failure cannot be prevented by any alternative private measure and a resolution action is necessary in the public interests. ${ }^{93}$ Hence, a bank may enter 
resolution while it is not (yet) balance-sheet insolvent and it has a positive equity value. ${ }^{94}$ The relevant resolution authority then has a toolbox at its disposal with four so-called 'resolution tools' 95 as well as several 'resolution powers' to assist the implementation of the tools, ${ }^{96}$ such as the power to amend or alter the maturity of debt instruments. ${ }^{97}$ Besides the bail-in tool ${ }^{98}$ the toolbox consist of three tools to arrange a transfer of (a part of) a bank's assets and liabilities or shares to a private sector purchaser, a bridge bank or a bad bank respectively. ${ }^{99}$

As has been noted above, the BRRD and SRM Regulation divide a resolution authority's bail-in powers between two different instruments, but many characteristics of the instruments are the same. ${ }^{100}$ To ensure that banks have a sufficient amount of capital instruments and liabilities on their balance sheets that can be made subject to bail-in, banks are required to meet at all times a minimum requirement for debt instruments and liabilities that are bail-inable, which is known as 'MREL' and is set by the resolution authority. ${ }^{101}$ MREL should in principle ensure that losses can be absorbed as well as that the bank can subsequently be recapitalised, although the recapitalisation requirement does not apply to banks that are expected to be liquidated if losses have been incurred. ${ }^{102}$ First, the write-down or conversion of capital instruments-tool under Articles 59 and $60 \mathrm{BRRD}$ and Article 21 SRM Regulation is exercised either independently from a resolution action and before the conditions for resolution are met, or in combination with the application of the resolution tools where a resolution procedure has already been commenced. ${ }^{103}$ Hence, this tool does not constitute a resolution tool within the definition of the BRRD and SRM Regulation. Its application has been considered a 'Kleiner Bail-in' 104 and precedes and or even prevents the application of the bail-in tool. ${ }^{105}$ The scope of the tool is limited to a write-down and/or conversion of only bank's so-called 'relevant capital instruments', which are AT1 and Tier 2 ('T2') instruments. ${ }^{106}$ Yet, according to recently published proposals of the European Commission to amend the BRRD and SRM Regulation, the scope of the tool should be extended to liabilities that meet the MREL requirements. ${ }^{107}$ Secondly, the bail-in tool under Articles 35 to 55 BRRD and Article 27 SRM Regulation is part of the mentioned resolution authority's toolbox in a resolution procedure and may be applied for two purposes, notwithstanding the fact that the authority also needs to be take into account the general resolution objectives and resolution principles. ${ }^{108}$ It may be used (i) to recapitalise the bank under resolution or (ii) to capitalise a bridge institution to which claims or debt instruments of the bank are transferred or complement the application of the resolution tools to transfer parts of the bank to a private sector purchaser or bad bank. ${ }^{109}$ Thus, the measures can be taken in relation to the existing bank, which approach is generally called an open-bank bail-in, as well as to a non-operating firm while a part of the business are transferred to a new entity, which is a so-called closedbank bail-in. ${ }^{110}$ As will be discussed below in paragraph 4.2.3, not all liabilities fall within the scope of the resolution authority's bail-in powers and the powers are to be applied tranche by tranche, ${ }^{111}$ following to a large extent 'a reverse order of priority of claims' ${ }^{112}$ under national insolvency law. ${ }^{113}$ Moreover, the amount to be bailed-in and the conversion rate is determined by the resolution authorities based on a valuation of the bank. ${ }^{114}$ Arguably, by placing a bank's AT1 and T2 instruments, which are typically 'issued as subordinate, loss-absorbing instruments from the outset', ${ }^{115}$ and according to the recently published proposals also liabilities that count as MREL within the scope of a separate tool for bail-in, the BRRD and SRM Regulation underline that holders of these instruments and claims stand at the top rungs of the loss distribution ladder and the instruments function as additional buffers for a crisis situation. ${ }^{116}$

A simple example illustrates the application of the bail-in mechanism under the BRRD and SRM Regulation. ${ }^{117}$ Suppose the ECB as supervisory authority concludes that a bank needs to take a substantial 
loss on its loan book and therefore no longer complies with the regulatory capital requirements. The conditions for the opening of a resolution procedure are met and the Single Resolution Board adopts a socalled resolution scheme. ${ }^{118}$ This scheme places the bank under resolution and determines the application of the resolution tools. Based on a valuation of the bank's assets and liabilities as well as a resolvability assessment that has been made and a resolution plan that has been drawn up beforehand, the Board assesses which resolution actions need to be taken, what part of the bank's capital should be made subject to bailin measures and what should in the end be the capital position of the bank, which is in this case the 'target' of the bail-in measures. ${ }^{119}$ In this hypothetical case, the resolution authority concludes that bailin is not combined with the application of other resolution tools. The resolution scheme enters into force after the European Commission and the Council have not expressed any objections within a period of 24 hours. ${ }^{120}$ The Board then sends the scheme to the relevant national resolution authorities, who implement the measures in accordance with the BRRD, as transposed into national law. ${ }^{121}$ The write-down and conversion of capital instruments-tool is first applied to reduce the nominal value of the share capital, ${ }^{122}$ the reserves and AT1 capital instruments in full to cover the losses and return the difference between the asset side and liability side of the bank's balance sheet to zero. ${ }^{123}$ The next step in this hypothetical bailin is the conversion of capital instruments and liabilities into shares or other instruments of ownership, such as instruments that give the right to acquire shares, ${ }^{124}$ to recapitalise the bank and ensure that it complies with regulatory capital requirements again. ${ }^{125}$ By contrast, if the bank would have had a positive net asset value, which from an economic point of view belongs to its shareholders, the resolution authority would only exercise its conversion powers. ${ }^{126}$ This means that the percentage of control in the bank and the value of the investments of the existing shareholders may be reduced but the shareholders do not fully lose their investments. ${ }^{127}$ Thus, in relation to a bank that is to be recapitalised the resolution authority is allowed to exercise its conversion power independently from its power to reduce capital instruments and liabilities, but the latter power can only be used together with the conversion power. ${ }^{128}$ It is worth noting that the bank resolution rules do not explicitly provide to what extent a resolution authority is empowered to convert a liability of the bank in another type of liability - such as the conversion of a senior liability in a subordinated liability that qualifies as AT1 or T2 capital. It has been noted, however, that if a resolution authority is empowered to convert a claim against the bank into shares in the bank, in theory it may also be empowered to convert the claim in a less subordinated position such as a subordinated claim. ${ }^{129}$ Moreover, one can also argue that Article 64 BRRD provides for a legal basis for this conversion as it provides that a resolution authority is empowered to modify the terms of a contract to which the bank under resolution is a party when exercising one of its resolution powers.

\section{Coherence in the national legal system}

This paragraph takes a detailed look at specific aspects of the interaction between bail-in under the BRRD and SRM Regulation on the one hand and more general areas of national private law on the other hand. Paragraph 4.1 illustrates that Dutch bank resolution law and general corporate insolvency law share some similar principles and policy goals. Yet, paragraph 4.2 discusses three aspects of bail-in, i.e. the effects of a debt write-down, the effects of a conversion of claims and the hierarchy of claims followed in bail-in, to demonstrate that several legal issues and challenges exist in terms of the effects of the application of bail-in in and its alignment with more general areas of Dutch private law.

\subsection{Alignment with certain principles and policy goals of insolvency law}

\subsubsection{Principles of insolvency law in the bank resolution framework}


The resolution principles that must be taken into account in the application of the bail-in mechanism under the BRRD and SRM Regulation reveal a first relationship between the bail-in framework and national insolvency law. At a general level, most of the nine principles listed in Article 34(1) BRRD and Article 15(1) SRM Regulation are essentially traditional principles of insolvency law. ${ }^{130}$ According to the resolution principles, the bank under resolution's shareholders bear first losses, its creditors bear losses after the shareholders, to a large extent in accordance with the ranking of claims recognised under national insolvency law, and creditors in the same class are treated in an equitable manner, unless otherwise provided. This means that in case of a bail-in losses are to be allocated pro-rata between claims of the same rank. ${ }^{131}$ It may remind one for instance of Section 3:277(1) of the Dutch Civil Code (Burgerlijk Wetboek, 'BW'), which provides that, in principle, creditors have amongst each other and in proportion to the amount of their claims an equal right to be paid from the net proceeds of the debtor's assets. Moreover, the Dutch Insolvency Act (Faillissementswet, 'Fw') provides that, apart from certain exceptions, in a suspension of payments procedure the payment of all debts existing before the commencement of this procedure may during the procedure only be made to all joint creditors in proportion to their claims. ${ }^{132}$ Arguably, the idea that insolvency risks are allocated to a company's shareholders and creditors is also borrowed from general insolvency law. ${ }^{133}$ By way of illustration, under Section 179 Fw creditors are only distributed any proceeds in liquidation after a realisation of the debtor's assets available to the unsecured creditors, whereas Section 2:23b BW provides that upon dissolution of a company shareholders are only paid after all creditors' claims have been satisfied. ${ }^{134}$

Other resolution principles are that a bank's management is to be replaced in a resolution procedure and persons responsible for the failure are held liable under national civil or criminal law. ${ }^{135}$ Moreover, a 'no creditor worse off principle' ('ncwo principle') applies. ${ }^{136}$ The BRRD and SRM Regulation require a valuer to compare the treatment of creditors and shareholders in a resolution procedure with the expected outcome if the bank at the moment the resolution decision is taken 'had entered into normal insolvency proceedings' under national law, which are apparently considered the only alternative to the resolution measures. ${ }^{137}$ The term is in Section 3a:20 of the Dutch Act on financial supervision (Wet op het financieel toezicht, 'Wft'), which is part of the provisions that transpose the BRRD into Dutch law, translated as a liquidation of the bank that takes place in either a liquidation procedure (faillissement) under the Fw or bank emergency procedure (noodregeling) under the Wft. It has been argued that with the ncwo principle the bank resolution rules seek to meet requirements in human rights legislation on interferences with property rights. ${ }^{138}$ Human rights legislation, however, does not require that the safeguards for creditors and shareholders are based on exactly this principle on the comparison with a hypothetical liquidation procedure. ${ }^{139}$ The ncwo principle as currently in place follows existing concepts of national insolvency law. For example, under Sections 153(2) and 272(2) Fw, a court denies confirmation (homologatie) of a proposed composition scheme within a liquidation procedure (a faillissementsakkoord) or within a suspension of payments procedure (a surséance-akkoord) if the assets of the insolvent estate considerably exceed the sum proposed in the scheme. According to literature and case law, this means that the court needs to assess whether the consideration for the creditors is significantly less than that given in a liquidation of the debtor's assets. ${ }^{140}$ Moreover, the proposed Section $373 \mathrm{FW}$ contains a safeguard for creditors and shareholders in the context of a compulsory composition (dwangakkoord). It provides that a court may refuse declaring a rejected compulsory composition generally binding if, in brief, classes of creditors and shareholders who rejected the composition would receive less than the payments they would receive in a hypothetical liquidation procedure. ${ }^{141}$ 
Unlike the approach followed by the Fw, however, the decision whether the resolution measures are taken and creditors and shareholders are bailed-in is in principle not dependent on the outcome of the valuation under the ncwo principle. Under the BRRD and SRM Regulation, creditors and shareholders are only compensated for any difference between the treatment in resolution and a liquidation procedure. ${ }^{142}$ Thus, if it is likely that a bank's shareholders would not have received anything in a liquidation of the bank, a cancellation of their shares by a resolution authority does not place them in a worse position and no compensation is awarded. ${ }^{143}$ It has been noted, however, that this does not mean that a resolution authority may not be cautious in the implementation of specific resolution measures. Its decision is likely to be based on preliminary valuations and hypothetical assumptions and the going concern perspective of the bail-in rules may require a large amount of liabilities to be bailed-in to ensure that a bank is sufficiently recapitalised, ${ }^{144}$ which may not always correspond with the gone concern approach that forms the basis for the valuation under the ncwo principle. ${ }^{145}$ It has been argued that the resolution authorities clearly have some flexibility in the exercise of their write-down and conversion powers if the valuation shows that the value of the bank's assets would be impaired significantly if the bank was placed in liquidation and that the creditors, therefore, would not have been paid back in full. ${ }^{146}$ Yet, the announcement of the liquidators of the Dutch DSB Bank, which failed in 2009, that they expect that the bank's senior unsecured creditors are going to be paid in full and that there is a chance that subordinated creditors can be fully paid in the end as well illustrates that it is not self-evident that a bank's creditors suffer significant losses in a liquidation procedure. $^{147}$

\subsubsection{Developments towards financial restructuring outside traditional full-fledged (bank) insolvency procedures}

\section{Financial restructuring outside traditional full-fledged corporate insolvency procedures}

An EU framework that deals with private international law issues in cross-border insolvency procedures is already in place for debtors other than certain types of financial institutions since $2002,{ }^{148}$ but harmonisation of substantive insolvency law in the EU was long considered difficult to achieve. ${ }^{149}$ The set-up and operation of general corporate insolvency procedures was, and to a large extent still is, left to national legislatures. More recently, several studies concluded that a certain degree of convergence of national substantive insolvency law is preferable and a process directed towards further harmonisation of specific areas of corporate insolvency law was set in motion at EU level. ${ }^{150}$ One of the areas the European Commission currently focuses on is 'preventive restructuring frameworks'. In November 2016 it published a proposal for a directive which, inter alia, aims to ensure '[...] that viable enterprises in financial difficulties have access to effective national preventive restructuring frameworks which enable them to continue operating. ${ }^{151}$ According to the proposal, the main aims of these frameworks would include enabling the avoidance of the insolvency of a company so as to maximise the total value to creditors, employees, owners and the economy as a whole and prevent unnecessary losses of jobs, knowledge and skills. ${ }^{152}$ They should facilitate the restructuring ${ }^{153}$ of corporate debtors ${ }^{154}$ 'where there is likelihood of insolvency'. ${ }^{155}$ More in particular, the frameworks should allow the adoption of a financial restructuring plan by a majority of the debtor's creditors that can bind dissenting classes of creditors if it is confirmed by a judicial or administrative authority at the end of the process and the latter creditors are not worse off than in a liquidation of the debtor's business. ${ }^{156}$ Shareholders may, rather than shall, be allowed to vote on the adoption of the plan in a separate class. ${ }^{157}$

The described developments towards the facilitation of a restructuring of a non-financial corporate debtor's debts or business as an alternative to formal insolvency procedures cannot be studied in isolation from 
national developments in the field of corporate insolvency law. Driven by regulatory competition as well as developments during the recent financial crisis, many EU Member States have recently introduced or proposed laws to reform their national insolvency legislation. ${ }^{158}$ Literature indicates that in most of these jurisdictions procedures have been introduced that allow a restructuring or reorganisation of a debtor's business. ${ }^{159}$ Common tendencies of insolvency procedures in some Member States several years ago included already that a composition or arrangement that is negotiated amongst the creditors can be made binding on a dissenting minority, that a reorganisation or restructuring procedure can be started at an early stage and the possibility that a moratorium or stay is imposed and a conversion of creditor claims into share capital is arranged. ${ }^{160}$

At this moment, Dutch law does not provide for an effective statutory tool to force dissenting creditors outside a formal insolvency procedure to agree with a financial restructuring. ${ }^{161}$ An informal out-of-court composition (akkoord) qualifies as a multiparty agreement and is governed by general rules of private law. ${ }^{162}$ The Fw allows an insolvent non-financial corporate debtor to propose a composition scheme to its creditors within a liquidation procedure or suspension of payments procedure but the scheme is upon confirmation by the court only binding to the non-secured creditors without preferential rights. ${ }^{163}$ Yet, in 2012 the Dutch legislature launched the legislative programme Recalibration of Bankruptcy law (Herijking Faillissementsrecht), which, inter alia, aims to amend the Fw so as to implement a legal basis for a compulsory composition outside a formal suspension of payments or liquidation procedure. ${ }^{164}$ According to the proposal, creditors and shareholders would vote in separate classes and may both be bound to a restructuring plan if the composition is declared binding by the court, which can also approve the composition if it has not been accepted but the classes who voted against 'could not have reasonably voted the way they did'. ${ }^{165}$ As was noted in the previous paragraph, the proposal adds that a negative vote of a class cannot be overruled if, in short, the class of creditors or shareholders would receive less from the

composition than through the liquidation of the company. ${ }^{166}$ It explicitly provides that the scheme may provide for a limitation of the rights of creditors and shareholders, including a waiver of a part of the claims or an exclusion of pre-emption rights. ${ }^{167}$

\section{Financial restructuring outside traditional full-fledged bank insolvency procedures}

As has been discussed above, facilitating an early restructuring and reorganisation has also been at the heart of the reforms in the field of bank insolvency law in the EU the last few years. Put differently, both in the field of general corporate insolvency law and bank insolvency law the EU legislature and some Member States' legislatures have sought to supplement traditional formal insolvency procedures with some form of ex-ante measures. ${ }^{168}$ Member States' insolvency procedures for non-financial corporate debtors and banks continue to show significant differences in objectives, form and content. ${ }^{169}$ Yet, common underlying policy goals in both areas of law at EU level as well as in several EU countries have been that restructuring procedures need to be open at an early stage of financial distress so as to preserve a company's viable business and avoid a failure. It resulted in both fields of law in (proposals for) procedures in which creditors and shareholders can be forced to agree to certain measures, although, as has been noted in literature, in the field of bank resolution law the adoption of a reorganisation or restructuring plan is not left to a creditors' vote and a court confirmation but to an administrative decision. ${ }^{170}$

Already in the years before the BRRD required Member States to amend their bank insolvency legislation, European jurisdictions introduced national bank resolution regimes to expand the options and tools available to national authorities to restructure a failing bank's business before the moment of commencing 
formal insolvency procedures. ${ }^{171}$ In the Netherlands, for instance, liquidation was basically one of the only options for a failing bank under Dutch bank insolvency law for a long time. ${ }^{172}$ Yet, in 2012 the domestic bank insolvency framework was amended to expand the expand the tools and powers available to national authorities to preserve a failing bank's business. The Intervention Act (Interventiewet) empowered DNB to transfer shares issued by or assets and liabilities of a failing bank to another bank or a bridge bank under Part 3 Wft. ${ }^{173}$ The Act also introduced Section 6:2 Wft, which empowers the Dutch Minister of Finance to expropriate securities issued by or issued with the cooperation of a bank or assets and/or liabilities of a bank if the situation of that bank is posing a serious and immediate threat to the stability of the financial system. ${ }^{174}$ Although the rules of the BRRD on the bail-in mechanism were only implemented in the Wft in November 2015, in 2013 the application of the new expropriation tool already resulted in investors being forced to accept the reorganisation measures and bearing a share in the costs of the recapitalisation of a bank. Both the first application of the tool in relation to financial conglomerate SNS Reaal and the introduction of the bail-in mechanism under the BRRD sparked a fierce debate about the question to what extent investors in senior debt, besides the shareholders and subordinated creditors, should contribute towards a recapitalisation of a bank. In the former case, the Dutch Minister of Finance offered expropriated subordinated creditors and shareholders no compensation. If the expropriation decision would not have been taken, SNS Reaal would have been liquidated and, according to the Minister, in that case hardly any proceeds from the realisation of assets would have been available for distribution to the shareholders and creditors. ${ }^{175}$ Awaiting the final court judgement on the compensation amount, ${ }^{176}$ the former subordinated creditors and shareholders of SNS Reaal are considered to have lost their investments and are considered to have been de facto bailed-in. ${ }^{177}$

\subsection{Some technicalities and effects of bail-in that require further alignment with national private law}

\subsubsection{Effects debt write-down}

Article 53(3) BRRD provides what is the effect of a full write-down of creditors' claims against a bank by a resolution authority. If the principal amount of or outstanding amount payable in respect of a bank's liability is reduced to zero, the liability as well as any obligations or claims arising in relation to it that are not accrued at the time when the power is exercised, are treated as discharged for all purposes and shall not be provable in any subsequent procedure in relation to the bank under resolution or any successor in any subsequent winding-up. If the liability is only partly written down, under Article 53(4) BRRD the liability is treated as discharged to the extent the amount is reduced and the relevant instrument or agreement that created the original liability continues to apply in relation to the residual amount. Literature has not devoted much attention to the meaning of these provisions, including the meaning of the phrases 'any obligations or claims arising in relation to it' and 'for all purposes'. ${ }^{178}$ It is the author's view that the provisions seek to ensure that if a claim against a bank is written down, the bailed-in (part of the) debt can no longer be collected from this bank. Article 53(3) and (4) BRRD does not interfere in the relationship with a third party who guarantees a bank's debt obligations.

In this view, a bank's creditor whose claim is written down does not lose the ability to claim against a surety (borg) in accordance with Section 7:850(1) BW. He has a claim against the surety because the bank as principal debtor was not able to pay off its debts as the claims were bailed-in. ${ }^{179}$ However, under this view the claim against the bank of a surety who satisfied the creditor, including the surety who subrogated into the rights of the creditor under Section 7:866 BW, is treated as discharged as it concerns a claim against the bailed-in bank. ${ }^{180}$ It is questionable whether the legislative history to Section 3a:25 Wft, which transposes Article 53(3) and (4) BRRD into Dutch law, is correct in indicating that if the bank and another debtor are jointly and severally liable, a write-down of the claim against the bank discharges the other joint and 
several debtor from his obligation against the creditor. ${ }^{181}$ By contrast, it is the author's view that if a parent company has issued a so-called '403 statement' (403-verklaring), i.e. a statement under which the parent company assumes joint and several liability for certain debts of its subsidiaries in accordance with Section 2:403 BW, a creditor can seek recourse against the parent company if the subsidiary's liabilities have been bailed-in. ${ }^{182}$ It has been argued that intra-group guarantees may put the effectiveness of a resolution strategy at risk, for instance because a parent company has guaranteed its subsidiaries' bail-inable debt and a write-down of a subsidiary's liabilities may result in claims under the guarantee and difficulties in separating different group entities and functions in a resolution procedure. ${ }^{183}$ Yet, these effects can be avoided by bailing-in the claim under the guarantee as well. Moreover, in literature doubts have arisen whether 'any obligations or claims arising in relation to it' can include the obligations of a protection seller under a credit default swap. ${ }^{184}$ If Article 53(3) and (4) BRRD and Section 3a:25 Wft do not limit the hedging possibilities of an investor in bail-inable debt through credit default swaps, for the sake of clarity the investor may prefer to include in the contract that the application of the resolution authority's write-down powers in relation to has claim constitutes an event of default. ${ }^{185}$

\subsubsection{Effects conversion of claims}

The question arises why only a write-down of a bank's liabilities would not be sufficient to recapitalise the bank. ${ }^{186}$ Although losses can be absorbed in this way, the BRRD and SRM Regulation explicitly require that any write-down to repair a negative equity value starts with a reduction of equity before liabilities can be written down. ${ }^{187}$ Moreover, the effect would be advantageous to the bank's existing shareholders because their share in the company's capital would not be affected and they may possibly benefit if the value of the company increases in the future while the resolution principle that shareholders bear the first losses is not adhered to. It follows that the power to reduce a bank's liabilities is logically linked to the powers to reduce equity and convert debt into equity. ${ }^{188}$

It has been noted that the BRRD requires national law to guide the formalities of the conversion. ${ }^{189}$ Yet, Section 3a:6 Wft, which implements Articles 54(3) and 63(2) BRRD, provides that, apart from certain exceptions, a resolution order is not subject to any approval, procedural or notification requirement and company law provisions on shareholders' voting rights or the general meeting of shareholders do not apply. ${ }^{190}$ Moreover, the application of the bail-in mechanism is not subject to any procedural impediment existing by virtue of law, statutes or contract, such as requirements on the authorised share capital of a company. Thus, if for the exercise of the conversion powers new shares need to be issued, these requirements are not considered an impediment to the issuance in excess of this maximum amount of share capital. ${ }^{191}$ It is the author's view that if creditors' claims are converted into shares, the claims are not assigned to the bank or set-off against the obligation of making capital contributions as would generally be the case in a debt to equity swap under Dutch law. ${ }^{192}$ The conversion would apply by operation of law. ${ }^{193}$ Bail-in under the Wft needs to be considered a measure sui generis which is for its application not dependent on the abovementioned requirements contained in Dutch company law. In essence the effect of the conversion is similar to the effect of the write-down of a claim as the claim itself extinguishes. ${ }^{194}$

Another important question is what the value of the equity stake is each bailed-in creditor should receive in exchange of his claim. ${ }^{195}$ It has been noted that this assessment initially depends on the value of the claim that is converted, on the ratio of the value of this claim to the value of the other claims, and, where relevant, on the value of the share capital represented by the 'old' shareholders, i.e. shareholders who have not been 'wiped-out' in the application of the bail-in mechanism. ${ }^{196}$ By way of example, according to the 
Dutch doctrinal majority opinion, which view is not the prevailing view in all EU Member States, ${ }^{197}$ in a debt-to-equity swap governed by general company law the nominal value of a claim — rather than for instance the amount the company is able to pay or the claim's market value - is the relevant value in the determination how much corresponding equity value is created. ${ }^{198}$ This means that even if the company would not have been able to pay a creditor back in full, the creditor would receive shares in the company for the claim's nominal value. ${ }^{199}$ By contrast, the BRRD, the SRM Regulation and the European Banking Authority ('EBA')'s draft regulatory technical standards on valuation under the BRRD seem to require that a resolution authority takes into account other types of valuations of creditors' claims too. The former two provide that the valuation of a bank's assets and liabilities to decide on the application of the bail-in mechanism and the extent of the write-down and conversion should be based on 'fair, prudent and realistic' assumptions. ${ }^{200}$ The draft standards emphasise the need to assess the economic value to ensure that all losses are recognised, which value may, according to the standards, deviate from the value presented in financial statements. ${ }^{201}$

Besides assessing the value of the creditors' claims, the resolution authority needs to determine the conversion rate of debt to equity. ${ }^{202}$ Article 50 BRRD provides in this context that the rate may be different for different classes of capital instruments and liabilities, provided that (i) it represents appropriate compensation to the affected creditors for any loss incurred and/or (ii) the conversion rate for liabilities that are considered senior under national insolvency law is higher than for liabilities that are treated subordinated. According to the EBA in its draft guidelines on the conversion rate under the BRRD, this means that authorities should seek to ensure that creditors and shareholders receive at least the value which they would have received had the bank been wound up under national insolvency law (the ncwo principle) as well as that the creditor hierarchy is fully respected. ${ }^{203}$ Thus, in principle each euro of subordinated creditors' claims should not receive more value of remaining debt and common equity claims than each euro of senior creditors' claims would receive. ${ }^{204}$ According to the EBA, the determination of the equity value that is distributed to bailed-in creditors is to be based on the estimated market price of the shares. ${ }^{205}$

Valuation methods, and more in particular the fact that in a debt restructuring procedure often only an estimated valuation of a corporate debtor's business can be advanced, does not only receive attention of lawyers specialised in bank resolution. For example, as was discussed in paragraph 4.1.1, if a composition scheme within a liquidation procedure or suspension of payments procedure under the Fw has been approved by the creditors, the court is required to make a valuation of the estate's assets to determine whether the assets considerably exceed the sum proposed in the scheme. ${ }^{206}$ Moreover, in insolvency law literature several alternatives have been proposed to overcome the uncertainties related to and disputes about valuation in reorganisation procedures, ${ }^{207}$ including the system with option rights to the company's shares for the different classes of shareholders and creditors that was proposed almost 30 years ago by Bebchuk. ${ }^{208}$ According to the latter proposal, the most junior class with shareholders can exercise the options against an exercise price equal to the value of all claims in the higher ranked assets. If they do, they are provided the shares and the company's creditors are paid in full. If they do not wish to exercise their options, the creditors in a more senior class are given to option to buy the shares, which process continues until all shares are sold. Whether the holders of the rights exercise the options depends on their own estimation of the company's value. ${ }^{209}$ Thus, by exercising their options shareholders and creditors who do not belong to the most senior class invest additional capital in the company. The participants can also sell their options in the market or use the equity as collateral to first borrow the money needed to become shareholder. ${ }^{210}$ In another well-known proposal of Roe, only a small part of the company's shares is first issued to the public. Based on the proceeds, the company's value is determined and the remaining 
shares are distributed to the company's creditors in accordance with the order of priority. ${ }^{211}$ Thus, both proposals rely on a form of market pricing.

Against this background, it cannot be a coincidence that DNB published a proposal on the operation of bailin in the Netherlands with its own market-based solution. According to the proposal, part of the application of the bail-in mechanism is the conversion of claims into rights to newly issued shares in the bank under resolution. Thus, claims that, according to the resolution authority, need to be converted into equity to recapitalise the bank are first converted into claim rights. Until these option rights are exercised, which may be traded in the market as in Bebchuk's proposal, the newly issued shares are placed by the bank with a foundation. ${ }^{212}$ Interestingly, this method does not only provide the resolution authority time to verify who the bank's creditors are as well as the creditors time to sell their positions if they do not want to or are not allowed to become shareholder of the bank. ${ }^{213}$ In a resolution procedure creditors and shareholders in principle do not have the chance to bargain over how much of the pie they are entitled to. Since the claim rights will have a certain value in the market, it is the author's view that the proposed method can ensure that the resolution authority has an impression of what the value of the bank in the market is and may, thereupon, help in deciding how much equity the bailed-in creditors should receive in exchange for their claim rights. However, although the proposed method is potentially useful in a bank resolution procedure, it is still unclear how the final text of DNB's approach to bail-in will look like and Dutch insolvency law does not have experience with such a market based method. ${ }^{214}$ Moreover, it has been argued that for the sake of clarity a procedure in which the conversion of claims is directly implemented may be advocated instead of the described procedure with claim rights. ${ }^{215}$

\subsubsection{The hierarchy of claims in bail-in}

\section{The hierarchy of claims under the BRRD}

Fundamental question in the design of a bank resolution framework is how the losses and costs of the recapitalisation of a bank under resolution should be allocated among all stakeholders. ${ }^{216}$ An order of priority of claims traditionally determines who are paid first out of the available pool of assets in a liquidation procedure under insolvency law, but in many jurisdictions this ranking or hierarchy is already also of relevance in other types of insolvency procedures, such as for the formation of classes of creditors in a reorganisation procedure. ${ }^{217}$ It has been noted that priorities recognised in an insolvency procedure generally reflect legal, social or moral decisions made and policy goals pursued in a specific jurisdiction, such as the protection of employees' claims for unpaid wages, ${ }^{218}$ and have often been developed over a long period of time. ${ }^{219}$ Following the distributional rules traditionally applicable in an insolvency procedure, it seems fair to assume that in most EU Member States shareholders would first be subject to bail-in, secondly subordinated creditors and thirdly unsecured, non-preferred creditors. ${ }^{220}$ Moreover, creditors who are granted priority in insolvency, which may include tax authorities, would be part of the group of creditors standing at the end of the line of creditors potentially subject to bail-in. This approach corresponds perfectly with the idea that creditors should not become worse off as a result of bail-in than in liquidation. ${ }^{221}$ However, it has been argued that in a resolution procedure public interests may need to be prioritised over the interests of the creditors inter se, which justifies a more functional approach. ${ }^{222}$ Liabilities subject to contagion risks, such as deposits, as well as liabilities arising from certain essential services and business lines may need to be excluded from bail-in to avoid that risks are spread to other parts of the financial sector

and bank runs occur as well as to enable the bank to continue its viable day-to-day operations. ${ }^{223}$ Thus, in the latter approach all liabilities of the bank can be made subject to write-down and conversion powers but 
some liabilities are exempted. ${ }^{224}$ Although this would mean that the latter liabilities preserve their original position in liquidation, in bail-in they are treated de facto senior to liabilities that are 'bail-inable'. 225

The BRRD and SRM Regulation follow a combination of the two mentioned approaches. ${ }^{226}$ In addition, they require that losses are imposed on capital instruments that count as AT1 and T2 instruments, which are subordinated claims of investors in the bank, before other subordinated liabilities. ${ }^{227}$ Only if AT1 and T2 instruments are reduced in full, other subordinated debt, including capital instruments that do not meet the criteria for AT1 or T2 instruments under CRR, ${ }^{228}$ and senior debt are reduced or converted in ascending order under national law. It is the author's view that four resolution principles set out in Article 34 BRRD and Article 15 SRM Regulation are relevant in this context: (i) the shareholders of the bank under resolution bear first losses; (ii) the creditors of the bank bear losses after the shareholders, in accordance with the hierarchy of claims under insolvency law, unless otherwise provided; (iii) the creditors in the same class are treated in an equitable manner, unless otherwise provided; and (iv) covered deposits are fully protected. ${ }^{229}$ The latter principle is complied with through the creation of depositor preference, which is further discussed below, as well as the exemption of that part of deposits covered by a deposit guarantee scheme from the scope of the bail-in mechanism. ${ }^{230}$ Other liabilities excluded from bail-in under the BRRD and SRM Regulation are (i) secured liabilities, ${ }^{231}$ (ii) liabilities arising from the holding of client assets or from the bank acting as a fiduciary in a fiduciary relationship, (iii) short-term liabilities to other institutions, (iv) short-term liabilities owed to payment and securities settlement systems, and (v) liabilities owed to employees, to commercial and trade creditors, to tax and social security authorities and to deposit guarantee schemes. ${ }^{232}$ Furthermore, the resolution authorities also have some discretion to exclude or partially exclude other liabilities in exceptional circumstances themselves in the resolution of a specific bank, and, accordingly, grant different treatment to claims that would rank equally in liquidation. The exclusion is for instance allowed if it is strictly necessary and proportionate to achieve the continuity of critical functions and core business lines. ${ }^{233}$ The BRRD and SRM Regulation explicitly indicate that this may mean that the level of write down or conversion of non-excluded instruments and liabilities needs to be increased, but the ncwo principle needs to be complied with. ${ }^{234}$

\section{The general insolvency ranking of claims under national law}

Against this background, the question arises how the hierarchy of bail-inable liabilities under the BRRD and SRM Regulation relates to the general insolvency ranking of claims under national law. ${ }^{235}$ Most of the Dutch provisions that grant priorities to certain types of creditors or claims can be found in the BW and specific statutes rather than the Fw. ${ }^{236}$ Central principles of the BW are that a creditor can have recourse for his claim against all property of his debtor, unless otherwise provided by law or agreement (Section 3:276 BW) as well as that creditors, in principle, have, amongst each other and in proportion to the amount of their claims, an equal right to be paid from the net proceeds of the assets of the debtor (Section 3:277 BW). ${ }^{237}$ Section 3:278 BW, however, provides that creditors who can assert a right of pledge, mortgage, preferential right (voorrecht), ${ }^{238}$ or another statutory ground for priority such as the possessory lien ${ }^{239}$ (retentierecht) are granted priority. Accordingly, in case of a 'concursus creditorum' a right of mortgage or right of pledge can be exercised as if the insolvency procedure had not been opened and tax authorities and employees have, among others, a right to preferential payment. ${ }^{240}$ Claims against the insolvency estate (boedelvorderingen), i.e. essentially the costs of the insolvency procedure, ${ }^{241}$ are to be paid in priority to all insolvency claims. ${ }^{242}$ Furthermore, several other instruments, such as set-off rights, grant creditors quasipriority (feitelijke preferentie). ${ }^{243}$ It has been noted that most of the priorities granted under Dutch law 
can be historically explained and that the reasons that for instance have been put forward in legislative history for the priority status of tax claims include that the public treasury cannot choose its debtors. ${ }^{244}$ The result is a complex system with many classes of creditors that need to be paid in priority to the ordinary unsecured, non-preferential insolvency creditors and the latter group of creditors often receives nothing in a liquidation procedure. ${ }^{245}$ Several authors believe that the principle that creditors have equal rights to proportional payment does not amount that much under Dutch insolvency law. ${ }^{246}$ Proposals to change the current system for the distribution of the realisation proceeds, for instance by limiting the scope of the administration claims (boedelvorderingen) and preferential claims, ${ }^{247}$ have been very much debated in legal literature but no significant changes have been adopted so far. ${ }^{248}$

As has been shown above, the bank resolution rules provide that creditors of the same class are to be treated in an equitable, rather than equal, manner ${ }^{249}$ and grant de facto priority to several categories of liabilities by excluding them from bail-in. ${ }^{250}$ Some of the excluded liabilities enjoy priority treatment under Dutch insolvency law, including liabilities to employees in relation to accrued salary, while other separate categories of liabilities, such as short term liabilities, are alien to the insolvency ranking of claims under Dutch law. ${ }^{251}$ Moreover, the differences between the treatment of a bank's liabilities in bail-in and in liquidation may increase further if resolution authorities decide to exercise the discussed discretionary exclusions of certain liabilities from bail-in.

Specific attention needs to be paid in that context to Article 108 BRRD, which further aligns the position of depositors and deposit guarantee schemes in insolvency procedures with their position in bail-in by requiring the insertion of two rungs to the insolvency ranking of claims under national law. ${ }^{252}$ It has been argued that the decision to exclude deposits from bail-in only up to the amount deposits are covered by the deposit guarantee scheme accords with the idea that the economic effects of a formal insolvency procedure for the bank's creditors should be replicated in a resolution procedure as far as possible. ${ }^{253}$ However, if covered deposits would only be excluded from the scope of bail-in, in a liquidation of the bank's assets under a Member State's insolvency law they are likely to rank equally with ordinary unsecured, non-preferred claims. The probability that creditors are entitled to compensation under the ncwo principle would then increase if the latter claims are bailed-in because the class of liabilities that can be touched in bail-in has become smaller. ${ }^{254}$ This justifies granting deposits from natural persons or micro, small and medium-sized enterprises a priority ranking in insolvency procedures which is higher than the ranking of the unsecured, non-preferred claims. ${ }^{255}$ Moreover, Article 108 BRRD provides that the part of these deposits that is covered by a deposit guarantee scheme has a ranking which is even higher than the ranking of the part that is not covered. A deposit guarantee scheme subrogating to the rights and obligations of covered depositors has the same preferred position as covered depositors. It has been noted that the BRRD leaves to national law the determination what a 'high priority ranking' means in this regard and how the priority position of depositors relates to the preferential positions of other creditors. ${ }^{256}$ It is questionable whether the leeway left to Member States in this respect is fully consistent with the aim of the BRRD to protect depositors and deposit guarantee schemes and give them a priority status. ${ }^{257}$ For example, under Section 212ra Fw the claims set out in Article 108 BRRD have a preferential position ('zijn bevoorrecht ${ }^{258}$ ) and are paid from the proceeds available in liquidation after the preferential insolvency claims listed in Section 3:288 BW, which include claims for wages relating to the work performed prior to the commencement of the insolvency procedure. Consequently, under Dutch law depositors and deposit guarantee schemes can assert a preferential right (voorrecht) in accordance with Section 3:278 BW but stand at the bottom of the class of preferential insolvency claims and are in a liquidation procedure only paid after all administration claims 
and other insolvency claims on the list of claims with priority treatment. ${ }^{259}$ In a liquidation procedure under Dutch law distributions are often hardly made to all preferential creditors. ${ }^{260}$ However, the liquidation of DSB Bank, as was already referred to in paragraph 4.1.1, shows that in practice this may be different in a procedure for liquidation of a bank's assets.

\section{Further alignment hierarchy of claims in bail-in and liquidation}

Article 108 BRRD contributes to the further alignment of the position of depositors and deposit guarantee schemes in resolution with their position in liquidation. ${ }^{261}$ Yet, it has been acknowledged in literature that the differences that still exist between the hierarchy and pool of claims that can be made subject to bail-in and the ranking of claims recognised under national insolvency law as well as the fact that Member States take different approaches to the insolvency ranking of claims create several complications. ${ }^{262}$ Firstly, the differences in the treatment of creditors and claims in liquidation under national laws may lead to differences in the application of the bail-in mechanism and may undermine authorities' incentives for cross-border cooperation. ${ }^{263}$ The resolution authorities need to decide in each resolution procedure which national insolvency law is applicable to determine the ranking of claims, which decision may become very complex in case of large and internationally operating banks and which makes it difficult for creditors to assess whether their claims might be bailed-in. ${ }^{264}$ By way of example, given that under the BRRD liabilities to tax authorities are only excluded from the scope of the bail-in tool if the liabilities are awarded preferential treatment under national law, these liabilities fall within the scope of the bail-in tool under the Wft but are not bail-inable in Member States in which tax claims are not granted priority. ${ }^{265}$ Secondly, the BRRD excludes liabilities such as unsecured liabilities to trade creditors from the scope of bail-in and debt linked to derivatives counterparties may be excluded by the resolution authority given the risks of contagion in case of an abrupt termination of derivatives transactions. ${ }^{266}$ However, as has been noted in literature, these claims would in a liquidation procedure traditionally be on equal footing with the claims of general unsecured creditors that are not protected in bail-in. ${ }^{267}$ Thus, in a bail-in of the claims of the latter group of creditors the risk exists that this group has a claim under the ncwo principle and that compensation may have to be paid as the group of creditors that bears the losses has become smaller, unless the losses that would otherwise be imposed on the mentioned excluded creditors are imposed on an external party. ${ }^{268}$ Related to this point, the BRRD creates a ranking within the layer of a bank's subordinated liabilities. Insolvency law traditionally does not make a distinction between debt instruments that meet the regulatory capital requirements (CET1, AT1 and T2 capital) on the one hand and other shares and subordinated liabilities on the other hand. Again, if national insolvency law does not follow the same ranking of creditor claims in liquidation, the risk exists that the exercise of the write-down and conversion powers results in certain subordinated creditors being disadvantaged compared to their position in a hypothetical liquidation procedure. ${ }^{269}$

Against this background, part of the amendments to the BRRD that were recently proposed by the European Commission is the proposal to add a paragraph to Article 108 BRRD, which aims to facilitate that the class of unsecured, non-preferred debt of banks can be split in two layers. According to the proposal, relevant contractual documentation of a bank should provide that certain short-term claims resulting from debt instruments that have no derivative features rank in insolvency below other senior unsecured claims resulting from debt instruments but higher than the classes of subordinated claims against a bank. ${ }^{270}$ Following the applicable ranking of claims in insolvency procedures, in this way the new class of claims can be bailed-in immediately after contractually or statutory subordinated claims but before claims exempted from bail-in, while the chance that resolution authorities need to treat claims with an equal ranking in liquidation in an unequal manner in bail-in is reduced. Moreover, the provision would facilitate the banks' compliance with the MREL requirements, especially because the provisions on MREL allow resolution 
authorities to require that MREL is met with instruments that rank in insolvency procedures below liabilities that are excluded from bail-in or may be excluded from bail-in by the resolution authority. ${ }^{271}$

Although it has been argued that national legislation governing the insolvency ranking of claims against a bank should be fully harmonised at EU level, ${ }^{272}$ according to others this is politically not feasible at the moment. ${ }^{273}$ Arguably, the fact that priorities recognised by national insolvency law can generally be justified on specific historical, cultural or policy grounds and are strongly intertwined with entitlements and priorities granted in other areas of law, such as security rights or privileges attached to tax claims under tax law, also shows that any harmonisation effort would need to deal with significant challenges. ${ }^{274}$ Moreover, it has been submitted that even if the distributional rules in liquidation are fully harmonised, differences may remain to exist since Member States may still protect certain types of creditors outside insolvency law, for instance via social security mechanisms. ${ }^{275}$ The mentioned Commission's proposal, however, does not require a statutory subordination but only deals with a contractual solution. ${ }^{276}$ It does not interfere into the many other areas of law that insolvency law interfaces and stays away from, for instance, harmonisation of all general private law priorities. ${ }^{277}$ In the present author's view, the proposal illustrates that there is openness - at least at EU level - towards further alignment of the treatment of specific classes of claims against banks under general insolvency law with their treatment in resolution.

\section{Conclusion}

The BRRD and SRM Regulation have introduced a complex EU bank resolution framework in which public interests may be given preference to individual interests, court involvement has been minimised and administrative resolution authorities have a wide range of tools and powers at their disposal to intervene in and reorganise a failing bank. This article highlighted that this framework does not function as a standalone substitute for Member States' insolvency laws but more general areas of national private law, in particular insolvency law, play an essential role in the interpretation and application of the bank resolution

rules. ${ }^{278}$ Moreover, it was discussed that the prevailing view in policy and academic discussions at the moment is that there is a need for further alignment of national substantive insolvency law with the bank resolution framework, while at the same time it is recognised that harmonisation efforts in the field of insolvency law face significant challenges. Against that background, the article examined that to what extent the bail-in rules, principles and objectives provided by the SRM Regulation and the implemented BRRD are in coherence with more general areas of Dutch private law. The analysis can be relevant for other EU Member States than the Netherlands as well. Moreover, it can serve as a basis for projects that aim at further development and harmonisation of the bank resolution framework and discuss which elements of national private law should be included in any future EU legislative instrument in that regard.

The ultimate objectives of the bank resolution rules are to a certain extent different than those of general corporate insolvency law. Yet, since in both Dutch general corporate insolvency law and bank insolvency law there has been a general trend towards the facilitation of early restructuring as an alternative to liquidation of a debtor's business as a whole while possibilities for shareholders and creditors to block restructuring measures are reduced under certain circumstances, it seems fair to say that both areas of law share some underlying policy goals. Moreover, it was shown that most of the resolution principles provided by the bank resolution rules can be found implicitly or explicitly in a similar form in Dutch general insolvency law. However, this contribution also revealed that several other relationships between the bail-in rules and more general areas of Dutch private law are inconsistent or unclear. The role and effect of guarantees in case of a write-down of creditor claims against a bank need clarification. Moreover, it was argued that the proposed procedure for the conversion of a bank's debts can be potentially useful to overcome issues related to valuation but its final design is not yet known and the procedure would 
derogate from the existing Dutch insolvency law practice. Finally, Section 212ra Fw contributes and the proposed amendments to Article 108 BRRD are likely to contribute to the further alignment of the order of priority of claims recognised under national insolvency law with the hierarchy and pool of claims that can be made subject to bail-in under the bank resolution rules. Yet, the author maintains that the remaining differences between the two fields make the application of bail-in and related safeguards for all parties involved, including shareholders, creditors and authorities, less transparent and more complex.

$*$

Lynette Janssen is a PhD candidate at Leiden University's Hazelhoff Centre for Financial Law under the supervision of Prof. Dr. W.A.K. Rank and Prof. Dr. M. Haentjens. The author is thankful to Prof. Dr. W.A.K. Rank and Prof. Dr. M. Haentjens for valuable comments on earlier draft versions of this article. The author has been awarded the Bronze Medal in the competition for the International Insolvency Institute's 2017 Prize in International Insolvency Studies. The article takes into account developments until 31 March 2017.

Westlaw. (C) 2017 Thomson Reuters. No Claim to Orig. U.S. Govt. Works.

Footnotes

1

2

3

4

5
For the sake of clarity and simplification, this article uses the term 'bank' to refer to a 'credit institution', which is the term used in EU legislative instruments. The scope of application of the European bank resolution framework is explained infra n. 16 \& 17 .

Cf. Recitals 1, 3-4 Directive 2014/59/EU of the European Parliament and of the Council of 15 May 2014 establishing a framework for the recovery and resolution of credit institutions and investment firms and amending Council Directive 82/891/EEC, and Directives 2001/24/EC, 2002/47/EC, 2004/25/EC, 2005/56/EC, 2007/36/EC, 2011/35/ EU, 2012/30/EU and 2013/36/EU, and Regulations (EU) No 1093/2010 and (EU) No 648/2012, of the European Parliament and of the Council (OJ L 173, 12.6.2014, p. 190) ('BRRD'); T. Beck, 'Bank resolution: a conceptual framework', in: P. Delimatsis \& N. Herger, Financial regulation at crossroads, Alphen aan den Rijn: Kluwer Law International 2011, p. 67-69; International Monetary Fund, 'Resolution of CrossBorder Banks - A Proposed Framework for Enhanced Coordination', 11 June 2010, p. 8-9.

See E.H.G. Hüpkes, 'Insolvency — why a special regime for banks?', in: Current Developments in Monetary and Financial Law, Washington: International Monetary Fund 2005, p. 471-513.

See Hüpkes 2005, supra n. 3, p. 480; E.H.G. Hüpkes, The Legal Aspects of Bank Insolvency: A Comparative Analysis of Western Europe, the United States and Canada, The Hague: Kluwer Law International 2000, p. 67 et seq.

What kind of insolvency procedure could be opened under national law in case of a bank failure differed (and to a large extent still differs) across Member States. Directive 2001/24/EC of the European Parliament and of the Council of 4 April 2001 on the reorganisation and winding up of credit institutions (OJ L 125, 5.5.2001, p. 15)('Windingup Directive') mainly harmonised the private international law rules for bank failures. It distinguishes between 'reorganisation measures' on the one hand (which used to be defined as '[...] measures which are intended to preserve or restore the financial situation of a credit institution and which could affect third parties' pre-existing rights, including measures involving the possibility of a suspension of payments, suspension of enforcement measures or reduction of claims' and now also include the application of resolution tools and exercise of resolution measures under Article 117 BRRD) and 'winding-up proceedings' on the other hand (which are defined as '[...] collective proceedings opened and monitored by the administrative or judicial authorities of a Member State with the aim of realising assets under the supervision of those authorities, including where the proceedings 
6

7

8

9

10

11

12

13

14

15

16

are terminated by a composition or other, similar measure'). See G. Moss et al. (eds.), EU Banking and Insurance Insolvency, Oxford: Oxford University Press 2017, Chapters 1-3 for a discussion of the Winding-up Directive.

J.-H. Binder, 'The position of creditors under the BRRD', 2015, available at ssrn.com, p. 4. Cf. Basel Committee on Banking Supervision, 'Report and recommendations of the cross-border bank resolution group', March 2010, Recommendation 10.

See Binder 2015, supra n. 6, p. 4; T.H. Jackson \& D.A. Skeel, 'Dynamic resolution of large financial institutions', Harvard Business Law Review 2 (2012), p. 447-448; M. Krimminger, 'Ending Too Big To Fail', in: R.M. Lastra (ed.) Cross-border Bank Insolvency, New York: Oxford University Press 2011, p. 284.

See M. Schillig, Resolution and insolvency of banks and financial institutions, Oxford: Oxford University Press 2016, p. 54-55; J.-H. Binder, 'Durchsetzung von Marktdisziplin mittels zwangsweiser übertragung systemrelevanter Teile von Banken?', Jahrbuch für die Ordnung von Wirtschaft und Gesellschaft 64 (2013), p. 387-388; Beck 2011, supra n. 4, p. 58-64.

See Schillig 2016, supra n. 8, p. 54-55; Beck 2011, supra n. 2, p. 53-54, 58-64.

See Schillig 2016, supra n. 8, p. 54-55; Beck 2011, supra n. 2, p. 59.

See e.g. Recitals 5, 45 BRRD. Cf. Schillig 2016, supra n. 8, p. 61-66; R.J. de Weijs, 'Too big to fail as game of chicken with the state: what insolvency law theory has to say about TBTF and vice versa', European Business Organization Law Review 14 (2013) no. 2, p. 201-224, who discuss the bank resolution rules on the basis of the insolvency law theory of anti-commons and its explanation of holdout behaviour.

See e.g. Recital 5, 15, 45, 46 and 60 BRRD; Impact Assessment Accompanying the document Proposal for a Directive of the European Parliament and of the Council establishing a framework for the recovery and resolution of credit institutions and investment firms and amending Council Directives 77/91/EEC and 82/891/EC, Directives 2001/24/EC, 2002/47/EC, 2004/25/EC, 2005/56/EC, 2007/36/EC and 2011/35/EC and Regulation (EU) No 1093/2010 (COM(2012) 280 final, 6.6.2012), p. 8.

See supra n. 2.

Regulation (EU) No 806/2014 of the European Parliament and of the Council of 15 July 2014 establishing uniform rules and a uniform procedure for the resolution of credit institutions and certain investment firms in the framework of a Single Resolution Mechanism and a Single Resolution Fund and amending Regulation (EU) No 1093/2010 (OJ L 225, 30.7.2014, p. 1).

On 23 November 2016 the European Commission published several proposals, including proposals to amend the BRRD and SRM Regulation. See Proposal for a Directive of the European Parliament and of the Council on amending Directive 2014/59/EU of the European Parliament and of the Council as regards the ranking of unsecured debt instruments in insolvency hierarchy (COM(2016) 853 final, 23.11.2016); Proposal for a Directive of the European Parliament and of the Council amending Directive 2014/59/EU on loss-absorbing and recapitalisation capacity of credit institutions and investment firms and amending Directive 98/26/EC, Directive 2002/47/EC, Directive 2012/30/EU, Directive 2011/35/EU, Directive 2005/56/EC, Directive 2004/25/EC and Directive 2007/36/EC (COM(2016) 852 final, 23.11.2016); Proposal for a Regulation of the European Parliament and of the Council amending Regulation (EU) No 806/2014 as regards loss-absorbing and Recapitalisation Capacity for credit institutions and investment firms (COM(2016) 851 final, 23.11.2016).

Besides banks and investment firms that have their registered office in the EU, the BRRD applies to certain EU (parent) financial holding companies as well as EU financial institutions that are a subsidiary of a bank, investment firm or holding company to which the BRRD applies and are covered by the supervision of the parent undertaking on a consolidated basis in accordance with the European Capital Requirements Regulation ('CRR') (see infra n. 39). Within this context, a financial institution is understood to 
be an undertaking other than a bank or an investment firm whose principal activity is to acquire holdings or to pursue certain financial activities, such as financial leasing, the participation in securities issues and the provision of services relating to such issues, and portfolio management and advice. Finally, the BRRD applies to branches of banks or investment firms that have their head office outside the EU. See Articles 1, 2(1)(2)(4), (9)-(15) BRRD; Articles 4(1)(1)-(2), (20)-(22), (26), (30)-(33) CRR; Annex I points 2-12, 15 Directive 2013/36/EU of the European Parliament and of the Council of 26 June 2013 on access to the activity of credit institutions and the prudential supervision of credit institutions and investment firms amending Directive 2002/87/EC and repealing Directives 2006/48/EC and 2006/49/EC (OJ L 176, 27.06.2013, p. 388)('CRD IV'); Articles 4(1)(1)-(2) and Annex I Section A, C Directive 2014/65/EU of the European Parliament and of the Council of 15 May 2014 on markets in financial instruments and amending Directive 2002/92/EC and Directive 2011/61/EU (OJ L 173, 12.06.2014, p. 349) ('MiFID II'). For a discussion of the scope of the BRRD, see Schillig 2016, supra n. 8, p. 98-100. The BRRD applies in the EU and is considered to be European Economic Area ('EEA') relevant, which requires an amendment to the EEA agreement with a view to allowing implementation of the BRRD in the EEA Member States that are not EU Member States.

The SRM Regulation applies to banks that have their registered office in participating EU Member States as well as to parent undertakings that are subject to and investment firms and financial institutions that are covered by the consolidated supervision carried out by the European Central Bank within the European Banking Union's Single Supervisory Mechanism ('SSM') and are established in participating EU Member States. The SRM Regulation links its scope of application to the scope of application of the SSM Regulation (Council Regulation (EU) No 1024/2013 of 15 October 2013 conferring specific tasks on the European Central Bank concerning policies relating to the prudential supervision of credit institutions (OJ L 287, 29.10.2013, p. 63)). See Articles 2, 4 SRM Regulation; Articles 2(1), 7 SSM Regulation. For a discussion of the scope of the SRM Regulation, see Schillig 2016, supra n. 8, p. 100-101. See e.g. Schillig 2016, supra n. 8, p. 54-55; S. Gleeson \& R. Guynn, Bank resolution and crisis management, Oxford: Oxford University Press 2016, p. 3-5; J.H. Binder, 'Komplexitätsbewältigung durch Verwaltungsverfahren? Krisenbewältigung und Krisenprävention nach der EU-Bankensanierungs- und -abwicklungsrichtlinie', ZHR Zeitschrift für das gesamte Handels- und Wirtschaftsrecht 179 (2015), p. 93-95, 105; J.-H. Binder, 'Resolution: concepts, requirements and tools', 2014, available at ssrn.com, p. 9. F.J. Garcimartín, 'Resolution tools and derivatives', in: M. Haentjens \& B. Wessels (eds), Bank Recovery and Resolution: A Conference Book, Den Haag: Boom Uitgevers 2014, p. 183 notes that bail-in entails a sort of 'synthetic insolvency'. Articles 32(5) BRRD and 18(5) SRM Regulation require that the 'winding-up' of the bank under 'normal insolvency proceedings' is considered first by the resolution authority. Articles 2(1)(54) BRRD and 3(1)(42) SRM Regulation provide a definition of the term 'winding-up': '[...] the realisation of assets [...]'. The term 'normal insolvency proceeding' is by Article 2(1)(47) BRRD defined as 'collective insolvency proceedings which entail the partial or total divestment of a debtor and the appointment of a liquidator or an administrator normally applicable to institutions under national law and either specific to those institutions or generally applicable to any natural or legal person'. 14 , who calls it 'regulatory insolvency'. See also Ch. Thole, 'Gläubigerschutz in einem Sonderinsolvenzrecht für Banken', in: P.S. Kenadjian (ed.), Too Big To Fail_-Brauchen wir ein Sonderinsolvenzrecht für Banken?, Berlin/Boston: Walter de Gruyter 2012, p. 220-221; A. Flessner, 'Das Insolvenzrecht für Banken Europäischer Rundblick und grundsätzliche Überlegungen', Österreichisches BankArchiv (2010), p. 656. 
Cf. Ch. Thole, 'Bankenabwicklung nach dem SAG', ZBB Zeitschrift für Bankrecht und Bankwirtschaft 28 (2016), p. 62, who notes about bail-in that '[i]n der Sache geht es um nichts anderes als um einen Forderungserlass undloder einen Debt-Equity-Swap, wie er im Insolvenzrecht seit Langem bekannt ist.'; A. Gracie, 'Resolution through the lens of corporate restructuring', Bank of England Speech, June 2012, p. 7, who notes that '[b]ailin is an idea that has been adopted from corporate debt restructurings'; D.G. Baird \& E.R. Morrison, 'Dodd-Frank for bankruptcy lawyers', ABI Law Review 19 (2011), p. 287 318 , who discuss that the resolution rules for financial institutions in the United States incorporate rather than reject traditional rules of bankruptcy law, although some special rules are provided.

Cf. e.g. Article 37(6) BRRD and Article 22(5) SRM Regulation, which provide that if only a part of the bank under resolution's assets, rights or liabilities are transferred to a private sector purchaser or a bridge institution, the residual entity is to be 'wound up under normal insolvency proceedings' within a reasonable timeframe. See supra n. 19 for the definition of the terms 'winding-up' and 'normal insolvency proceedings'. See infra paragraph 4.1.2.

Cf. B. Wessels, Faillietverklaring, Deventer: Kluwer 2016, para. 1001.

Contra Schillig 2016, supra n. 8, p. 9-11, who prefers to use the term 'resolution' as umbrella term for both the application of the resolution tools and powers and a formal insolvency procedure.

Cf. e.g. W.-G. Ringe, 'Bail-in between liquidity and solvency', University of Oxford Legal Research Paper Series no. 33/2016, 2016, available at ssrn.com; B.P.M. Joosen, 'Regulatory capital requirements and bail in mechanisms' in: M. Haentjens \& B. Wessels, Research Handbook on Crisis Management in the Banking Sector, Cheltenham/ Northampton: Edward Elgar 2015, p. 175-235; T.F. Huertas, 'The case for bail-ins', in: A. Dombret \& P.S. Kenadjian (ed.), The Bank Recovery and Resolution Directive. Europe's solution for "Too Big To Fail”?, Berlin/Boston: Walter de Gruyter 2013, p. 167188.

M. Haentjens, 'National Insolvency Law in International Bank Insolvencies', in B. Santen \& D. van Offeren (eds.), Perspectives on international insolvency law: A contribute to Bob Wessels, Deventer: Kluwer, 2014, p. 72-73; BRRD Impact Assessment, supra n. 12 , p. 79.

See supra n. 19 and see Recitals 45, 46, 49 and Article 32(1), (5) BRRD; Recital 61 and Article 18(1), (5) SRM Regulation; Section 212ha Dutch Insolvency Act (Faillissementswet).

Article 48 BRRD; Article 17 SRM Regulation.

De Nederlandsche Bank, 'Operation of the bail-in tool in the Netherlands', English consultation version, June 2016, available at www.dnb.nl, p. 9. Cf. Section 2:64 of the Dutch Civil Code (Burgerlijk Wetboek).

See supra n. 5.

Council (EC) Regulation no. 1346/2000 of 29 May 2000 on insolvency proceedings (OJ L 160, 30.6.2000, p. 1), which will soon be replaced by Regulation (EU) 2015/848 of the European Parliament and the Council of 20 May 2015 on insolvency proceedings (recast) (OJ L 141, 5.6.2015, p. 19).

F.J. Garcimartín, 'The review of the EU Insolvency Regulation: Some general considerations and two selected issues (hybrid procedures and netting arrangements), in: L. Lennarts \& F.J. Garcimartín, The review of the EU Insolvency Regulation: Some proposals for amendment, Netherlands Association for Comparative and International Insolvency Law Reports 2011, p. 21; M. Virgós \& F.J. Garcimartín, The European Insolvency Regulation: Law and Practice, The Hague: Kluwer Law International 2004, p. $9-10$. 
B. Wessels, 'The hermeneutic circle of European insolvency law', in: E.H. Hondius et al. (eds.), Contracteren internationaal, Den Haag: Boom Juridische Uitgevers 2006, p. 351-368.

B. Wessels, 'On the future of European insolvency law', INSOL Europe Academic Forum's $5^{\text {th }}$ Edwin Coe lecture 2012, p. 10; Garcimartín 2011, supra n. 34, p. 21.

See R.M. Lastra, 'Northern Rock, UK bank insolvency and cross-border bank insolvency', Journal of Banking Regulation 9 (2008), p. 165; J. Bolzico et al., 'Practical guidelines for effective bank resolution', World Bank Policy Research Working Paper no. 4389, November 2007, p. 5-8; Ch. Hadjiemmanuil, 'Bank resolution policy and the organisation of bank insolvency proceedings: critical dilemmas', in D.G. Mayes \& A. Liuksila (eds), Who Pays for Bank insolvency? Hampshire/New York: Palgrave Macmillan 2004, p. 289-291; European Shadow Financial Regulatory Committee, 'Dealing with Problem Banks in Europe', Statement no. 1, June 1998.

Cf. Recitals 2, 11 \& 21; Proposal for a Regulation of the European Parliament and of the Council establishing uniform rules and a uniform procedure for the resolution of credit institutions and certain investment firms in the framework of a Single Resolution Mechanism and a Single Bank Resolution Fund and amending Regulation (EU) No 1093/2010 of the European Parliament and of the Council (COM(2013) 520 final, 10.7.2013), p. 6-7.

See Proposal for a Directive of the European Parliament and of the Council on amending Directive 2014/59/EU of the European Parliament and of the Council as regards the ranking of unsecured debt instruments in insolvency hierarchy (COM (2016) 853 final, 23.11.2016); The Council Conclusions on a roadmap to complete the Banking Union of 17 June 2016, available at www.consilium.europa.eu; K.-Ph. Wojcik, 'Bail-in in the Banking Union', Common Markets Law Review 53 (2016) no. 1, p. 123-137; D. Valiante, 'Harmonising insolvency laws in the Euro Area: rationale, stock-taking and challenges. What role for the Eurogroup?', July 2016, available at www.europarl.europa.eu, p. 2225; Schillig 2016, supra n. 8, p. 366. Cf. Communication from the Commission to the European Parliament, the Council, the European Central Bank, the European Economic and Social Committee and the Committee of the Regions, 'Towards the completion of the Banking Union' (COM(2015) 587 final, 24.11.2015), p. 9-10. Wojcik 2016, supra n. 39, p. 124-126, 130-137; Valiante 2016, supra n. 39, p. 22-25; K.-Ph. Wojcik, 'The significance and limits of the "no creditor worse off" principle for an effective bail-in', ECB Legal Conference 2015, 'From Monetary Union to Banking Union, on the way to Capital Markets Union, New opportunities for European integration', September 2015, available at www.ecb.europa.eu, p. 254-258. See e.g. H. Eidenmüller, 'Contracting for a European insolvency regime', 2017, available at ssrn.com, p. 3; Valiante 2016, supra n. 39, p. 31-32; F. M. Mucciarelli, 'Not just efficiency: insolvency law in the EU and its political dimension', European Business Organization Law Review 14 (2013), p. 196-199; G. Cherubini et al., 'Harmonisation of Insolvency Law at EU level', Note requested by the European Parliament's Committee on Legal Affairs, 2010 (no. PE 419.633), p. 27. I. Fletcher \& B. Wessels, Harmonisation of Insolvency Law in Europe, Deventer: Kluwer, 2012 discuss, among other things, the latter note (p. 36-40) and the reasons for and disadvantages to the harmonisation of insolvency law at EU level (p. 40-51). See also H. Eidenmüller, 'Comparative corporate insolvency law', 2016, available at ssrn.com, for a comparative analysis of corporate insolvency law in the United States, England, France and Germany (stating, inter alia, that '[...] if certain divergences are rooted in different regulatory philosophies or even in differences between "deep normative structures" of particular societies, then harmonization might be positively harmful — at least from the perspective of those jurisdictions whose regimes are replaced by harmonization'), as well as Ch. G. Paulus, 'Verbindingslinien des modernen Insolvenzrechts', Zeitschrift für Wirtschaftsrecht (2000), p. 2189-2195, who 
discusses that German insolvency law is by its nature closely connected to many areas of law.

Cf. Haentjens 2014, supra n. 28, p. 69-83, for a discussion of the BRRD's bank resolution framework and Dutch insolvency law from a coherence perspective.

J. Adolff \& C. Eschweg, 'Lastenverteilung bei der Finanzmarktstabilisierung', ZHR Zeitschrift für das gesamte Handelsrecht und Wirtschaftsrecht 177 (2013), p. 962, also cited by Binder 2015, supra n. 18, p. 120.

Thole 2016, supra n. 22, p. 67.

D. Bliesener, 'Legal problems of bail-ins under the EU's proposed Recovery and Resolution Directive', in: A. Dombret \& P.S. Kenadjian (eds.), The Bank Recovery and Resolution Directive. Europe's solution for "Too Big To Fail”?, Berlin/Boston: Walter de Gruyter 2013, p. 191.

Ringe 2016, supra n. 27, p. 3.

To be sure, in Euro Area Member States, national law only transposes those rules of the BRRD that are not provided by the SRM Regulation.

See J.M. Smits, 'Coherence and fragmentation in the law of contract', in: P. LettoVanamo \& J.M. Smits, Coherence and fragmentation in European private law, Munich: Sellier European law publishers 2012, p. 13-17; J.M. Smits, 'The complexity of transnational law: coherence and fragmentation of private law', 2010, available at ssrn.com, p. 117-118; W. van Gerven, 'Koophandel zonder wetboek. Synthese en slotbeschouwingen', in: A. Bruyneel et al., Bicentenaire du Code de Commerce Tweehonderd jaar Wetboek van Koophandel, Brussels: De Boeck \& Larcier 2007, p. 380381; M. Haentjens, Harmonisation of Securities Law: Custody and Transfer of Securities in European Private Law, Alphen aan den Rijn: Kluwer Law International 2007, p. $21-$ 27; M.W. Hesselink, The new European legal culture, Deventer: Kluwer 2001, p. 37-49. $C f$. M. Haentjens, 'Incoherentie verenigd: privaatrechtelijke concepten onder druk van Europees recht', Inaugural lecture at the University of Ghent, March 2016, who sets out that several recent developments in the field of EU financial law put pressure on existing traditional concepts of national private law. Cf. also K. Langenbucher, 'Zur Auflösung von Systemspannungen zwischen Bankenaufsichtsrecht und Privatrecht', in: S. Grundmann et al. (eds.), Festschrift für Klaus J. Hopt zum 70. Geburtstag am 24. August 2010. Unternehmen, Markt und Verantwortung. Band 1, Berlin/New York: De Gruyter 2010, p. 2475-2187, who examines that banking supervisory norms set out in the international Basel framework may conflict with certain rules of national private law and their interaction may lead to 'regelrechten Systemspannungen'.

Haentjens 2007, supra n. 48, p. 41. Cf. J.M. Smits \& P. Letto-Vanamo, 'Introduction', in: P. Letto-Vanamo \& J.M. Smits, Coherence and fragmentation in European private law, Munich: Sellier European law publishers 2012, p. 6-7, who discuss that solutions can be proposed at EU as well as national level to deal with adverse consequences of the modern-day multi-level system of private law and especially cooperation and coordination between actors at the two levels is of importance.

See Smits \& Letto-Vanamo 2012, supra n. 49, p. 2-3.

Cf. K. Tuori, Ratio and voluntas. The tension between reason and will in law, Surrey/ Burlington: Ashgate 2011, p. 164-167; Smits 2012, supra n. 48, p. 10; Haentjens 2007, supra n. 48, p. 17-20.

See Smits \& Letto-Vanamo 2012, supra n. 49, p. 2-3; Smits 2012, supra n. 48, p. 1012; K. Kress, 'Coherence', in: S. Patterson (ed.) A Companion to Philosophy of Law and Legal Theory, West Sussex: Blackwell Publishing, 2010, p. 521 \& 528-530; Haentjens 2007, supra n. 48, p. 17-20.

See from a legal theoretical perspective Haentjens 2007, supra n. 48, p. 20; J. Desmet, 'The Structure of Law from a Legislative Point of View', in: A. Frändberg \& M. Hoecke (eds.), The Structure of Law, Uppsala: Iustus Förlag 1987, p. 133-139. See from an insolvency law perspective Wessels 2012, supra n. 34, p. 9-10; B. Laukemann, 'Structural aspects of 
harmonization in European insolvency law', Le temps et le droit. Hommage au professeur Closset-Marchal, Brussels: Bruylant 2013, p. 386-387. Cf. T. Juutilainen, 'Coherence through uniform private international law of property', in: P. Letto-Vanamo \& J.M. Smits, Coherence and fragmentation in European private law, Munich: Sellier European law publishers 2012, p. 104; Tuori 2011, supra n. 51, p. 162 for a distinction between 'local coherence' and 'total coherence'.

Articles 43, 59 BRRD; Articles 21, 27 SRM Regulation.

M. Olaerts, 'De omzetting van vorderingen in aandelenkapitaal: een metamorfose in het licht van de tweede richtlijn', 2003, available at iuscommune.com, p. 4; J.N. SchutteVeenstra, Harmonisatie van het kapitaalbeschermingsrecht in de EEG, Deventer: Kluwer 1991, p. 6-7.

For a theoretical discussion of the functions and structure of a bank's capital, see D.W. Diamond \& R.G. Rajan, 'A theory of bank capital', The Journal of Finance 55 (2000), p. 2431-2465.

See Gleeson \& Guynn 2016, supra n. 18, p. 196; S. Gleeson, 'Legal aspects of bank bailins', LSE Financial Markets Group Paper Series 205 (2012), p. 14; Financial Services Authority, 'A regulatory response to the global banking crisis', Discussion Paper 09/2, March 2009, available at www.fca.org.uk, p. 62-70. See also A. Cahn \& P. Kenadjian, 'Contingent Convertible Securities: From Theory to CRD IV', Institute for Law and Finance Working Paper Series (2014) no. 143, p. 1-2; P.S. Kenadjian, 'CoCos and BailIns', in: A. Dombret \& P.S. Kenadjian (ed.), The Bank Recovery and Resolution Directive. Europe's solution for "Too Big To Fail"?, Berlin/Boston: Walter de Gruyter 2013, p. 229, who argues that loss-absorbing capital instruments are important because banks '[...] operate with a very thin equity capital layer of a few percent, one that would be inconceivably think outside the financial sector, which can be eaten through every quickly by losses and which, as we saw in the 2008/2009 crisis, can be very hard to replace, especially in the midst of a crisis.'

See Schillig 2016, supra n. 8, p. 65-66.

See Schillig 2016, supra n. 8, p. 281-285; Gleeson \& Guynn 2016, supra n. 18, p. 196198; Joosen 2015, supra n. 27, p. 187 et seq.; Cahn \& Kenadjian 2014, supra n. 57, p. $1-$ 2; Kenadjian 2013, supra n. 57, p. 229; Gleeson 2012, supra n. 57, p. 14.

See e.g. Schillig 2016, supra n. 8, p. 281-285; S. Avdjiev et al., 'CoCos: a primer', BIS Quarterly Review, September 2013; C. Pazarbasioglu et al., 'Contingent Capital: Economic Rationale and Design Features', IMF Staff Discussion Note SDN/11/01 January 2011; C.W. Calomiris \& R.J. Herring, 'Why and How to Design a Contingent Convertible Debt Requirement', 2011, available at ssrn.com.

See Gleeson 2012, supra n. 57, p. 14; Pazarbasioglu et al. 2011, supra n. 60, p. 4; Basel Committee on Banking Supervision, 'Basel III: A global regulatory framework for more resilient banks and banking systems' (December 2010, revised version June 2011); Basel Committee on Banking Supervision, 'Proposal to ensure the loss absorbency of regulatory capital at the point of non-viability' (August 2010), p. 4-5. Besides a way to provide banks an additional source of capital and loss absorbing capacity, contingent capital instruments are considered to be a market discipline mechanism. Investors may have more incentives to monitor the operations of the bank since the write-down and conversion characteristics may expose subordinated debt holders to potential losses and shareholders to a potential dilution. See Cahn \& Kenadjian 2014, supra n. 57, p. 4; E. Avgouleas, Governance of financial Markets: the law, the economics, the politics, Cambridge: Cambridge University Press 2012, p. 362; Calomiris \& Herring 2011, supra n. 60, p. 21; J.C. Coffee, 'Bail-ins versus bail-outs: using contingent capital to mitigate systemic risk', Columbia University School of Law The Center for Law and Economic Studies Working Paper (2010), no. 380, available at ssrn.com, p. 35, 42; G. De Martino et al., 'Questioni di Ecnonomia e Financa, Countercyclical contingent capital (CCC): possible use and ideal design', Banca d'Italia 2010, p. 7. 
Regulation (EU) No 575/2013 of the European Parliament and of the Council of 26 June 2013 on prudential requirements for credit institutions and investment firms and amending Regulation (EU) No 648/2012 (OJ L 176, 27.6.2013, p. 1). See Articles 52(1)(n), 54(1), 92(1)(a) CRR; Joosen 2015, supra n. 27, p. 216-221. Joosen 2015, supra n. 27, p. 228; Bliesener 2013, supra n. 45, p. 191; Kenadjian 2013, supra n. 57, p. 229-230; J. Zhou et al., 'From bail-out to bail-in: mandatory debt restructuring of systemic financial institutions', IMF Staff Discussion Note SDN/12/03, April 2012, p. 6. See Joosen 2015, supra n. 27, p. 216; Gleeson 2012, supra n. 57, p. 15. See Schillig 2016, supra n. 8, p. 283-284. Joosen 2015, supra n. 27, p. 229 calls it a 'double dip'. A.D.S. Hoeblal \& J.J.A. Wiercx, 'Bail-in: over de (wettelijke) beperking van rechten van crediteuren', Maandblad voor Vermogensrecht (2013), no. 10, p. 272 call it a '[...] tweetrapsraket die noodlottige gevolgen lijkt te hebben voor een crediteur die op basis van contractuele voorwaarden als pleister op de wonde een aandelenbelang wist te verwerven, maar datzelfde belang vervolgens weer op het spel ziet staan door een besluit van de afwikkelingsautoriteit.'

T. Tröger, 'Regulatory influence on market conditions in the Banking Union: the cases of macro-prudential instruments and the bail-in tool', European Business Organization Law Review 16 (2015) no. 3, para. 3.2; Ch. Goodhart \& E. Avgouleas, 'A critical evaluation of bail-ins as bank recapitalization mechanisms', Centre for Economic Policy Research Discussion Paper 10065, 2014, available at ssrn.com, p. 3, who refer to Huertas 2013, supra n. 27, p. 167-169 for the discussion of the replacement of the public subsidy with private penalty, and to J.N. Gordon \& W.-G. Ringe, 'Bank resolution in the European Banking union, a translantic perspective on what it would take', Columbia Law Review 115 (2015), no. 5, p. 1300 and KPMG, 'Bail-in liabilities: Replacing public subsidy with private insurance', July 2012, available at www.kpmg.com, for the concept of private insurance or self-insurance. On the comparison with an insurance, see also Zhou et al. 2012, supra n. 64, p. 7. For a discussion of the concept of burden sharing in the context of bank resolution, see A. Gardella, 'Bail-in and the financing of the SRM', in: D. Busch \& G. Ferrarini, European Banking Union, Oxford: Oxford University Press 2015, p. 376 et seq.; S.N. Grünewald, The Resolution of Cross-Border Banking Crises in the European Union: A Legal Study from the Perspective of Burden Sharing, Alphen aan den Rijn: Kluwer Law International 2014. Cf. Joosen 2015, supra n. 27, p. 222, arguing that '[i]n the BRRD the bail in mechanism is placed in the context of penalization of creditors and shareholders, rather than a burden sharing mechanism that was the original concept of the international authorities advocating the contingent capital mechanism.'

Wojcik 2016, supra n. 39, p. 127; Binder 2015, supra n. 6, p. 18; J.H. Sommer, 'Why Bail-In? And How!', FRBN Y Economic Policy Review (2014), p. 217 et seq.; Binder 2014, supra n. 18, p. 29, as also referred to by Tröger 2015, supra n. 67, para. 3.2.

Ringe 2016, supra n. 27, p. 18-22. Many authors believe, however, that the bail-in mechanism is only suitable for an idiosyncratic bank failure and its implementation in a systemic crisis is problematic. See Goodhart \& Avgouleas 2014, supra n. 67, p. 37; Binder 2014, supra n. 18, p. 24.

P. Jenkins, 'Bank bondholders need rights like shareholders', Financial Times 18 April 2016.

Coffee 2010, supra n. 61, p. 42-44.

Cf. Ch. Hadjiemmanuil, 'Bank stakeholders' mandatory contribution to resolution financing: principle and ambiguities of bail-in', ECB Legal Conference 2015, 'From Monetary Union to Banking Union, on the way to Capital Markets Union, New opportunities for European integration', September 2015, available at www.ecb.europa.eu, p. 231-236.

B. Adler, 'Financial and political theories of American corporate bankruptcy', Stanford Law Review 45 (1993), p. 311-346. For a discussion of Adler's proposal, see Schillig 
2016, supra n. 8, p. 281, who discusses the chameleon equity firm also in the context of contingent capital and bail-in.

Adler 1993, supra n. 72, p. 323 et seq.

See Thole 2016, supra n. 22, p. 62; Gracie 2012, supra n. 22, p. 4.

Cf. D. Sach \& A. Bopp, 'The changing landscape of restructuring and bankruptcy law and its challenges for financial institutions', in: T.M. Hajjiri et al. (eds.), Global insolvency and bankruptcy practice for sustainable economic development, Palgrave Macmillan 2016, p. 74-75.

See Article 43(2) BRRD. Cf. Sach \& Bopp 2016, supra n. 76, p. 77-79; N.W.A. Tollenaar, 'Debt for equity swaps', in: N.E.D. Faber et al. (eds.), De bewindvoerder, een octopus, Deventer: Kluwer 2008, p. 63.

See E.H.G. Hüpkes, 'Revolution in resolution: loss-absorption, recapitalisation and restructuring of distressed banks', Butterworths Journal of International Banking and Financial Law (2015), p. 35; Kenadjian 2013, supra n. 57, p. 235. Cf. Articles 10-14 BRRD; Articles 8-9 SRM Regulation.

See e.g. N.W.A. Tollenaar, Het pre-insolventieakkoord. Grondslagen en raamwerk, Deventer: Kluwer 2016, p. 58-64; J. Hummelen, Distress Dynamics in bankruptcy, Eleven International Publishing 2016, p. 21-67; Draft explanatory memorandum to the Wet Continuïteit Ondernemingen II, 14 August 2014, available at www.internetconsultatie.n1/ wco2, p. 3; H. Eidenmüller, Unternehmenssanierung zwischen Markt und Gesetz, Köln: Verlag Dr. Otto Schmidt 1999, p. 31; T.H. Jackson, The logic and limits of bankruptcy law, Washingon: BeardBooks 2001 (reprint 1986), p. 211-215.

Cf. Articles 32, 59(3) BRRD; Articles 18, 21(8) SRM Regulation.

Schillig 2016 supra n. 8, p. 61-66; Hadjiemmanuil 2015, supra n. 72, p. 231-234; De Weijs 2012, supra n. 11, p. 217-221. Cf. R.J. de Weijs, 'Harmonisation of European insolvency law and the need to tackle two common problems: common pool and anticommons', International Insolvency Review 21 (2012), p. 67-83.

At the end of 2016, bondholders of the Italian Banca Monte dei Paschi di Siena were proposed a voluntary conversion of their claims into equity. See R. Sanderson, 'Monte dei Paschi di Siena wins approval for debt-to-equity swap', Financial Times, 16 December 2016.

The core elements of the European bank resolution regime are inter alia based on the principles developed by the Financial Stability Board. See Financial Stability Board, Key Attributes of Effective Resolution Regimes for Financial Institutions, 2011, updated in 2014, available at www.fsb.org. See also BRRD Impact Assessment, supra n. 12, p. 4 $5,50,78$.

For a discussion of differences between the resolution regimes in the United States and the EU, see M. Krimminger \& M.J. Nieto, 'Closing financial institutions on both sides of the Atlantic, Are there differences in approach?', CEPS Commentary, 25 February 2015. See Schillig 2016, supra n. 8, p. 15-38; Binder 2015, supra n. 18, p. 88-93; T.F. Huertas, 'Too big to fail: A policy's beginning, middle and end (?)', in: M. Haentjens \& B. Wessels, Research Handbook on Crisis Management in the Banking Sector, Cheltenham/ Northampton: Edward Elgar 2015, p. 3-23.

See supra note 16; Wojcik 2016, supra n. 39, p. 93-95; G.S. Zavvos \& S. Kaltouni, 'The Single Resolution Mechanism in the European Banking Union: Legal foundation, governance structure and financing', in: M. Haentjens \& B. Wessels, Research Handbook on Crisis Management in the Banking Sector, Cheltenham/Northampton: Edward Elgar 2015, p. 117-118.

See Recitals 10, 44 and Article 37(9) BRRD.

See Article 6(4)-(6) SSM Regulation; Article 7(2)-(5) SRM Regulation.

See Recitals 10, 11 SRM Regulation; Wojcik 2016, supra n. 39, p. 100-104; Zavvos \& Kaltouni 2015, supra n. 86, p. 125.

Article 3 BRRD. 
91
On the Dutch designated resolution authority, see Section 3a Decision implementing EU regulations financial markets (Besluit uitvoering EU-verordeningen financiële markten); Kamerstukken II 2014/15, 34208, nr. 3, p. 43. For an overview of all designated resolution authorities in EU Member States, see the list of designated resolution authorities of the European Banking Authority of August 2016, available at www.eba.europa.eu. See Article 6(4)-(6) SSM Regulation; Article 7(2)-(5) SRM Regulation. Article 32(1), (4), (5) BRRD; Article 18(1), (4), (5) SRM Regulation. See Recital 41 BRRD; Gleeson \& Guynn 2016, supra n. 18, p. 14, 173. Article 37(3) BRRD; Article 22(2) SRM Regulation.

Articles 63-72 BRRD.

Article 63(1)(j) BRRD.

Articles 43-55 BRRD; Article 27 SRM Regulation. Articles 38-42 BRRD; Articles 24-26 SRM Regulation. See Wojcik 2016, supra n. 39, p. 106, 112.

Article 45 BRRD; Article 23 SRM Regulation; Commission Delegated Regulation (EU) 2016/1450 of 23 May 2016 supplementing Directive 2014/59/EU of the European Parliament and of the Council with regard to regulatory technical standards specifying the criteria relating to the methodology for setting the minimum requirement for own funds and eligible liabilities (OJ L 237, 3.9.2016, p. 1). According to recently published proposals, Articles 45 BRRD and 12 SRM Regulation should be replaced by several articles with more extensive MREL requirements. See Proposal for a Directive of the European Parliament and of the Council amending Directive 2014/59/EU on lossabsorbing and recapitalisation capacity of credit institutions and investment firms and amending Directive 98/26/EC, Directive 2002/47/EC, Directive 2012/30/EU, Directive 2011/35/EU, Directive 2005/56/EC, Directive 2004/25/EC and Directive 2007/36/EC (COM(2016) 852 final, 23.11.2016); Proposal for a Regulation of the European Parliament and of the Council amending Regulation (EU) No 806/2014 as regards lossabsorbing and Recapitalisation Capacity for credit institutions and investment firms (COM(2016) 851 final, 23.11.2016).

Article 2(2) Commission Delegated Regulation (EU) 2016/1450 of 23 May 2016 supplementing Directive 2014/59/EU of the European Parliament and of the Council with regard to regulatory technical standards specifying the criteria relating to the methodology for setting the minimum requirement for own funds and eligible liabilities (OJ L 237, 3.9.2016, p. 1). See also Article 45c(2) Proposal for a Directive of the European Parliament and of the Council amending Directive 2014/59/EU on loss-absorbing and recapitalisation capacity of credit institutions and investment firms and amending Directive 98/26/EC, Directive 2002/47/EC, Directive 2012/30/EU, Directive 2011/35/EU, Directive 2005/56/EC, Directive 2004/25/EC and Directive 2007/36/EC (COM(2016) 852 final, 23.11.2016); Article 12d(2) Proposal for a Regulation of the European Parliament and of the Council amending Regulation (EU) No 806/2014 as regards loss-absorbing and Recapitalisation Capacity for credit institutions and investment firms (COM(2016) 851 final, 23.11.2016).

Articles 37(2), 59(1) BRRD; Articles 21(1), 22(1) SRM Regulation. The European Commission, however, has proposed to amend Articles 59 BRRD and 21 SRM Regulation so that the tool can only be exercised independently from a resolution action in relation to instruments internally within a banking group. See Proposal for a Directive of the European Parliament and of the Council amending Directive 2014/59/EU on loss-absorbing and recapitalisation capacity of credit institutions and investment firms and amending Directive 98/26/EC, Directive 2002/47/EC, Directive 2012/30/EU, Directive 2011/35/EU, Directive 2005/56/EC, Directive 2004/25/EC and Directive 2007/36/EC (COM(2016) 852 final, 23.11.2016); Proposal for a Regulation of the European Parliament and of the Council amending Regulation (EU) No 806/2014 
as regards loss-absorbing and Recapitalisation Capacity for credit institutions and investment firms (COM(2016) 851 final, 23.11.2016).

L. Hübner \& S. Leunert, 'Sanierung und Abwicklung von Banken nach SAG und SRMVO', Zeitschrift für Wirtschaftsrecht (2015), no. 47, p. 2263.

Wojcik 2016, supra n. 39, p. 112.

Articles 59(1), 2(1)(74) BRRD; Articles 21(1), 3(1)(51) SRM Regulation.

See Proposal for a Directive of the European Parliament and of the Council amending Directive 2014/59/EU on loss-absorbing and recapitalisation capacity of credit institutions and investment firms and amending Directive 98/26/EC, Directive 2002/47/ EC, Directive 2012/30/EU, Directive 2011/35/EU, Directive 2005/56/EC, Directive 2004/25/EC and Directive 2007/36/EC (COM(2016) 852 final, 23.11.2016); Proposal for a Regulation of the European Parliament and of the Council amending Regulation (EU) No 806/2014 as regards loss-absorbing and Recapitalisation Capacity for credit institutions and investment firms (COM(2016) 851 final, 23.11.2016).

See Articles 31(2), 34(1) BRRD; Articles 14(2), 15(1) SRM Regulation.

Article 43(2) BRRD; Article 27(1) SRM Regulation; Wojcik 2016, supra n. 39, p. 107.

See Binder 2015, supra n. 18, p. 109-110. On these two different resolution approaches, i.e. the open bank bail-in and the closed bank bail-in approach, see Krimminger \& Nieto 2015, supra n. 84, p. 5; L. Chennells \& V. Wingfield, 'Bank failure and bail-in: an introduction', Bank of England Quarterly Bulletin (2015) no. 3, p. 234. In the former case, the BRRD and SRM Regulation do not allow that the debt restructuring measures are applied in an isolated manner but require that they are accompanied with the creation of a plan that sets out measures to restore the bank's long term viability. Article 52 BRRD; Article 27(16) SRM Regulation. This requirement has been argued to be based on insights gained in the existing insolvency practice. See Thole 2016, supra n. 22, p. 61. See also T.F. Huertas, Safe to fail, Hampshire/New York: Palgrave Macmillan 2014, p. 105-106.

Cf. G. Franke et al., 'Effective Resolution of Banks, problems and solutions', Zeitschrift für Vergleichende Rechtswissenschaft (2014), p. 556-569, p. 565, who compare the hierarchy of liabilities in bail-in to a securitization transaction in which also several tranches are distinguished.

Wojcik 2016, supra n. 39, p. 111.

See Article 48 BRRD; Article 17 SRM Regulation; Thole 2016, supra n. 22, p. 62.

See Articles 36, 46, 48, 50, 60 BRRD; Article 20 SRM Regulation; European Banking Authority, Consultation Paper, Draft Regulatory Standards on valuation under Directive 2014/59/EU, EBA/CP/2014/38; European Banking Authority, Consultation Paper, Draft Guidelines on the rate of conversion of debt to equity in bail-in, EBA/ CP/2014/39; European Banking Authority, Consultation Paper, Draft Guidelines on the treatment of shareholders in bail-in or the write-down and conversion of capital instruments, EBA/CP/2014/40. See also paragraph 4.2.2.

Deutsche Bundesbank Monthly Report, 'Europe's new recovery and resolution regime for credit institutions', June 2014, available at www.bundesbank.de, p. 38.

Wojcik 2016, supra n. 39, p. 112; Binder 2015, supra n. 18, p. 108. According to Binder 2015, supra n. 18, p. 106-108 the current distinction made for bail-in under the BRRD and SRM Regulation between a bank's regulatory capital instruments on the one hand, which consist of subordinated liabilities and hybrid instruments, and other liabilities on the other hand may be somewhat confusing. He notes that '[d]ie systematische Grenze zwischen dem Anwendungsbereich der Artt. 43 ff. BRRD und demjenigen der Artt. $59 \mathrm{ff}$. BRRD verläuft somit quer durch die unterschiedlichen Kategorien hybrider Finanzierungsinstrumente.'

For a detailed discussion of the application of the bail-in mechanism, see e.g. Wojcik 2016, supra n. 39, p. 111; Gleeson \& Guynn 2016, supra n. 18, p. 177-181, 190-192; S. Schelo, Bank Recovery and Resolution, Alphen aan den Rijn: Kluwer Law International 
2015, p. 121-125; S. Andrae, 'Sanierung und Abwicklung von Kreditinstituten', in: A. Igl \& H. Heuter (eds.), Sanierungsplanung - Bankpraktische Umsetzung der MaSan, Köln: Bank-Verlag 2014, p. 30-31; Gleeson 2012, supra n. 57, p. 5-8.

See Article 18(1), (6), 23 SRM Regulation.

See Articles 10-14, 36(1), (4), 59(10) BRRD; Articles 8-9, 20(1), (5) SRM Regulation. Article 18(7) SRM Regulation. For a more detailed discussion of the decision-making procedure within the SRM, see Schillig 2016, supra n. 8, p. 147-150; Zavvos \& Kaltouni 2015, supra n. 86 , p. 127-138.

Articles 18(9), 23, 29 SRM Regulation.

Strictly speaking, equity does not fall within the scope of one of the two discussed bail-in instruments. The resolution principles as well as the specified hierarchy of liabilities in bail-in, however, provide that share capital must always be reduced first. Articles 47(1), 48(1)(a), 60(1) BRRD; Article 21(10) SRM Regulation. See T.F. Huertas, 'European Bank Resolution: Making it Work!', Interim Report of the CEPS Task Force on Implementing Financial Sector Resolution, January 2016, p. 16, who notes that '[s] trictly speaking, common equity is not subject to bail-in as it already bears first loss and is the instrument in which bail-in may convert other liabilities.' and see European Banking Authority, Consultation Paper, Draft Guidelines on the treatment of shareholders in bail-in or the write-down and conversion of capital instruments, EBA/CP/2014/40, p. 5, which sets out at '[s] hareholders sit at the bottom of the insolvency creditor hierarchy, and are therefore the first creditors to absorb losses on both a going-concern basis and in an insolvency. This position should be reflected in resolution, where shareholders should also be the first to absorb losses, and do so before more senior creditors.'

See Article 60(1) BRRD; Articles 21(10)-(11), 29 SRM Regulation.

Article 2(1)(61) BRRD.

See Articles 46, 48(1), 60(1) BRRD.

Article 47(1)(b) BRRD.

See European Banking Authority, Consultation Paper, Draft Guidelines on the treatment of shareholders in bail-in or the write-down and conversion of capital instruments, EBA/CP/2014/40; De Weijs 2012, supra n. 11, p. 221-223, who discusses that the fact that under the BRRD creditors may be forced to accept a conversion of their claims into equity while the shareholders do not lose their stake, although the shares are diluted, shows that the BRRD does not fully adhere to a so-called absolute priority rule. See Gesetzentwurf der Bundesregierung, BRRD-Umsetzungsgesetz, Deutscher Bundestag, Drucksache 18/2575, 22 September 2014, p. 172.

G.W. Kastelein, De bankenunie en vertrouwen in een goede afwikkeling, Deventer: Kluwer 2014, p. 129.

Cf. Schelo 2015, supra n. 117, p. 79, who notes that resolution is an insolvency-like process and the principles applicable in an insolvency procedure are therefore also applicable in bank resolution. Yet, it should be noted as a preliminary point that although this paragraph argues that the main features of most of the principles relevant to deciding on the application of the bail-in mechanism fit well together with principles traditionally recognised in insolvency procedures under national law, a more detailed look at the resolution rules reveals that the bail-in framework has its own peculiarities. As will be further discussed below in paragraph 4.2.3, the resolution rules take the ranking of claims recognised under national insolvency law as the starting point in bail-in but amend certain aspects of the order. As a result, the classes of creditors who are to be treated in an equitable manner under general insolvency law may not have the same composition as the classes of creditors recognised in the application of bail-in.

Article 48(2) BRRD; Article 17(1) SRM Regulation.

Section 233 Fw. See B. Wessels, Sursuance van betaling, Deventer: Kluwer 2014, para. 8190-8198. 

in" _ Gläubigerbeteiligung in einer Bankenkrise und die Behandlung von Treuhandverhältnissen', Deutsche Zeitschrift für Wirtschafts- und Insolvenzrecht (2015), p. 445. See also Binder 2015, supra n. 18, p. 105; Binder 2015, supra n. 6, p. 2-3. Cf. Burkert \& Cranshaw 2015, supra n. 133, p. 445, for a similar comparison with German insolvency law.

Cf. e.g. Section 2:138 BW which provides that on the insolvency of a public limited company, each director shall be jointly and severally liable to the insolvent estate for the amount of the liabilities to the extent that these cannot be satisfied out of the liquidation of the other assets, if the management has manifestly performed its duties improperly and if it is plausible that this is an important cause of the insolvency. The other resolution principles provided by Articles 34 BRRD and 15 SRM Regulation are that the bank's management must to provide all necessary assistance for the achievement of the resolution objectives and that resolution actions are to be taken in accordance with the safeguards provided by the BRRD and SRM Regulation respectively. Moreover, covered deposits need to be protected in a bank resolution procedure, which corresponds with the protection granted to deposits up to the amount of EUR 100,000 by the Dutch deposit guarantee scheme if a bank would enter a formal insolvency procedure. See Articles 2(1)(94), 44(2)(a) BRRD; Articles 2(1)(5), 6 Directive 2014/49/EU of the European Parliament and of the Council of 16 April 2014 on deposit guarantee schemes (OJ L 173 12.6.2014, p. 149); Section 3:259(2) Wft. For a general note on the interaction between deposit guarantee schemes and a bank resolution framework, see Gleeson \& Guynn 2016, supra n. 18, p. 20-26. See supra n. 19 for the definition of the term 'normal insolvency proceeding' and see Articles 34(1)(g) and 73-75 BRRD; Article 15(1)(g) SRM Regulation; Article 3a:20 Wft. For more details on the valuation that needs to be made, see European Banking Authority, Consultation Paper, Draft Regulatory Standards on valuation under Directive 2014/59/EU, EBA/CP/2014/38. For a discussion of the ncwo principle, see Wojcik 2016, supra n. 39, p. 120-126. Strictly speaking, under the BRRD and SRM Regulation the application of the write-down or conversion of capital instruments-tool is not covered by the ncwo-principle, in contrast to the application of the bail-in tool. Yet, it has been argued that this may not be compatible with the right to property in human rights legislation and investors in AT1 and T2 instruments should also have the benefit of the principle. See V.P.G. de Serière \& D.M. van der Houwen, "No creditor worse off" in case of bank resolution: food for litigation?', Journal of International Banking Law and Regulation 31 no. 7 (2016), p. 378; Wojcik 2016, supra n. 39, p. 121; Gleeson \& Guynn 2016, supra n. 18, p. 169. Valiante 2016, supra n. 39, p. 25; Wojcik 2015, supra n. 40, p. 255-257; B.J. Attinger, 'Crisis Management and Bank Resolution: Quo Vadis, Europe?', European Central Bank Legal Working Paper Series 13 (2011), p. 10-11. Cf. Kastelein 2014, supra n. 129, p. 146. 2013, para. 6116. Section 153(2) Fw uses the terms 'considerably exceed' ('aanmerkelijk te boven gaan') whereas Section 272(2) Fw only uses the term 'exceed' ('te boven gaan'). See Tollenaar 2016, supra n. 79, p. 360-364; S.W. van den Berg, 'WCO II: de cram down beschouwd vanuit waarderingsperspectief', Financiering, Zekerheden en Insolventierechtpraktijk (2014) no. 7; Draft explanatory memorandum to the Wet Continuïteit Ondernemingen II, 14 August 2014, available at www.internetconsultatie.nl/ wco2, p. 67-69.

142

\section{Article 75 BRRD.}

See Wojcik 2016, supra n. 39, p. 120-122, 132.

Gleeson \& Guynn 2016, supra n. 18, p. 179 note that in theory a resolution authority only needs to apply its write-down and conversion powers to ensure that the relevant bank 
is recapitalised and complies exactly with the relevant regulatory capital requirements, including the minimum CET1 requirement of 4.5 percent of risk-weighted assets under Article 92 CRR. Yet, Article 46(2) BRRD and Article 27(13) SRM Regulation provide that the application of the bail-in tool has to be directed towards sustainment of ' $[. .$. sufficient market confidence in the institution under resolution or bridge institution and enable it to continue to meet, for at least one year, the conditions for authorisation and to carry out the activities for which it is authorised [...]'. This may, according to Gleeson \& Guynn 2016, supra n. 18, p. 179, require a recapitalisation of the bank up to an even higher capital requirement. See also Article 2(5), (7) Commission Delegated Regulation (EU) 2016/1450 of 23 May 2016 supplementing Directive 2014/59/EU of the European Parliament and of the Council with regard to regulatory technical standards specifying the criteria relating to the methodology for setting the minimum requirement for own funds and eligible liabilities (OJ L 237, 3.9.2016, p. 1).

Wojcik 2016, supra n. 39, p. 123-126; Gleeson \& Guynn 2016, supra n. 18, p. 174, 180181; Adolff \& Eschwey 2013, supra n. 43, p. 969-971. See also Thole 2016, supra n. 22, p. 60-61; Binder 2015, supra n. 6, p. 10-13; Wojcik 2015, supra n. 40, p. 256-257; V.P.G. de Serière, 'Bail in: some fundamental questions', in: M. Haentjens \& B. Wessels (eds.), Bank Recovery and Resolution, A Conference Book, Den Haag: Boom Juridische uitgevers 2014, p. 178.

146 Gleeson \& Guynn 2016, supra n. 18, p. 174, 180-181.

See Faillissementsverslag nummer 34 van de curatoren van DSB Bank N.V. 31 January 2017, available at www.dsbbank.nl. Cf. Gleeson \& Guynn 2016, supra n. 18, p. 181.

The EU Insolvency Regulation and the recast EU Insolvency Regulation, see supra $\mathrm{n} .33$. See B. Wessels, 'Harmonization of Insolvency Law in Europe', European Company Law 8 (2011), p. 27-31.

See for an overview of the developments in the field of the harmonisation of specific aspects of national company and insolvency law since 2011, including the policy documents published by the European Parliament and the European Commission, European Commission, 'Initiative on insolvency', Inception Impact Assessment, 2 March 2016, available at ec.europa.eu; B. Wessels, 'Business rescue in insolvency law Changing the laws and challenges for the profession', Tijdschrift voor vennootschapsrecht, rechtspersonenrecht en ondernemingsbestuur (2015), p. 208-212; H. Eidenmüller \& K. van Zwieten, 'Restructuring the European Business Enterprise: The EU Commission Recommendation on a New Approach to Business Failure and Insolvency', 2015, available at ssrn.com, p. 8-11; S. Madaus, 'The EU recommendation on business rescue - only another statement or cause of legislative action across Europe?', Insolvency Intelligence 27 (2014), p. 82. For a comparative study of substantive insolvency law in the EU, see G. McCormack et al., 'Study on a new approach to business failure and insolvency. Comparative legal analysis of the Member States' relevant provisions and practices', Study requested by the European Commission, January 2016, available at ec.europa.eu.

Recital 1 Proposal for a Directive of the European Parliament and of the Council on preventive restructuring frameworks, second chance and measures to increase the efficiency of restructuring, insolvency and discharge procedures and amending Directive 2012/30/EU (COM (2016) 723 final, 22.11.2016). See for an extensive discussion of the proposal, Eidenmüller, 2017, supra n. 41. Only Title II of the proposed directive focuses on preventive restructuring frameworks.

Recital 2 Proposal, supra n. 151. It is worth noting that the proposal has now been criticised for failing to take into account that only viable companies should have the opportunity to restructure and the others should be liquidated. Eidenmüller 2017, supra n. 41, p.17-19. Cf. Tollenaar 2016, supra n. 79, p. 305-311.

Article 2(2) Proposal, supra n. 151 defines 'restructuring' as '[...] changing the composition, conditions, or structure of a debtor's assets and liabilities or any other part of 
the debtor's capital structure, including share capital, or a combination of those elements, including sales of assets or parts of the business, with the objective of enabling the enterprise to continue in whole or in part.'

Article 1(2) Proposal, supra n. 151, excludes several categories of financial institutions, including banks, from the scope of the proposal.

Article 4 Proposal, supra $\mathrm{n}$. 151.

Articles 8-11 Proposal, supra n. 151.

Article 12 Proposal, supra n. 151.

Eidenmüller \& Van Zwieten 2015, supra n. 150, p. 2-3; Wessels 2015, supra n. 150, p. 207; Wessels 2011, supra n. 149, p. 28.

Wessels 2015, supra n. 150, p. 207-208.

Wessels 2015, supra n. 150, p. 208 \& 210; A. Pieckenbrock, 'Das ESUG - fit für Europa?', Neue Zeitschrift für das Recht der Insolvenz und Sanierung 2012, p. 905-912; B. Wessels, 'Europe deserves a new approach to insolvency proceedings', European Company Law 4 (2007), p. 255. See also Commission Staff Working Document Impact Assessment Accompanying the document Proposal for a Directive of the European Parliament and of the Council on preventive restructuring frameworks, second chance and measures to increase the efficiency of restructuring, insolvency and discharge procedures and amending Directive 2012/30/EU (SWD(2016) 357 final, 22.11.2016), p. 15-22; De Weijs 2012, supra n. 81, p. 74-75. Pieckenbrock's study includes insolvency laws in England, France, Italy, Belgium, Austria and Germany. Two other common tendencies discussed by Pieckenbrock are that the debtor can be allowed to keep control over its business and that new financing for the business is protected.

See R.D. Vriesendorp et al., 'Herijking faillissementsrecht en het informeel akkoord: gemiste kans of opportunity voor een Nederlandse scheme of arrangement?', Tijdschrift voor Insolventierecht (2013), para. 2.

See Wessels 2013, supra n. 140, para. 6201 et seq.

Articles 157, 273 Fw. See Wessels 2013, supra n. 140, para. 6141-6144.

The consultation documents that were published in August 2014 can be found at www.internetconsultatie.n1/wco2. At this moment it is unknown when a formal proposal for the WCO II will be published. See Kamerstukken II 2015/16, 33 695, nr. 10. For a discussion of the proposed WCO II, see Hummelen 2016, supra n. 79, p. 205-223; A.M. Mennens \& P.M. Veder, 'Clementie en recht: het dwangakkoord buiten insolventie', Nederlands Tijdschrift voor Burgerlijk Recht (2015) no. 1, para. 4; E. Schmieman, 'De aanbeveling van de Europese Commissie inzake een nieuwe aanpak van faillissement en insolventie', Ondernemingsrecht (2014), p. 369-373.

According to the draft explanatory memorandum this criterion is comparable to the criterion used as regards a composition in a liquidation or suspension of payments procedure. See Draft explanatory memorandum to the Wet Continuiteit Ondernemingen II, 14 August 2014, available at www.internetconsultatie.n1/wco2, p. 68. Cf. Sections 146, 268a Fw; Hummelen 2016, supra n. 79, p. 191-195; Wessels 2013, supra n. 140, para. 6086.

Proposed Section 373 Fw; Draft explanatory memorandum to the Wet Continuitteit Ondernemingen II, 14 August 2014, available at www.internetconsultatie.nl/wco2, p. 68. Proposed Section $368 \mathrm{Fw}$; Draft explanatory memorandum to the Wet Continuiteit Ondernemingen II, 14 August 2014, available at www.internetconsultatie.n1/wco2, p. 46. Cf. Proposal, supra n. 139; Wessels 2007, supra n. 160, p. 255-256.

Wessels 2015, supra n. 150, p. 207; Wessels 2007, supra n. 160, p. 255.

Schillig 2016 supra n. 8, p. 61-66; Hadjiemmanuil 2015, supra n. 72, p. 231-234; De Weijs 2012, supra n. 11, p. 219-221, who all discuss that the bank resolution rules are designed to resolve the problem arising from the strategic holdout behaviour of stakeholders. See also supra paragraph 2.2 and see M. Haentjens, 'The changing role of the judiciary in insolvency: the case of bank resolution', in: R. Parry \& P.J. Omar (eds.), Banking and 
Financial Insolvencies: The European Regulatory Framework, Nottingham/Paris: INSOL Europe, p. 13-32, who discusses that in many jurisdictions new rules of both corporate insolvency law as well as bank resolution law have minimised the role of a court. Under the latter rules the role of the insolvency court is taken over by government authorities. For a discussion of the amendments to the bank insolvency frameworks in Germany and the United Kingdom since 2008, see A. Bornemann, 'Germany' in: M. Haentjens \& B. Wessels (eds.), Research Handbook on Crisis Management in the Banking Sector, Cheltenham/Northampton: Edward Elgar Publishing 2015, p. 452-495 and L. Verrill \& P. Durban, 'United Kingdom (Engeland and Wales)' in: M. Haentjens \& B. Wessels (eds.), Research Handbook on Crisis Management in the Banking Sector, Cheltenham/ Northampton: Edward Elgar Publishing 2015, p. 525-549 respectively.

According to the Dutch legislature in 2012, the supervisory instruments and powers the supervisory authorities DNB and the Authority Financial Markets (Autoriteit Financiële Markten) had at their disposal in those days were mainly preventive in nature. In case a bank ran into severe financial difficulties, the Wft provided for tools that were primarily geared towards an imminent liquidation of the bank. In a bank emergency procedure (noodregeling) under Article 3:160 Wft or a liquidation procedure the transfer of some part of the bank's business to a third party could be affected by the administrator or liquidator respectively, but at that stage the bank would be considered a gone concern. DNB did not have the power to head for a timely and orderly resolution of the institution by requiring a forced transfer of some or all activities of the institution as a going concern. See Kamerstukken II 2011/12, 33059, no. 3, p. 1-4.

Wet van 24 mei 2012 tot wijziging van de Wet op het financieel toezicht en de Faillissementswet, alsmede enige andere wetten in verband met de introductie van aanvullende bevoegdheden tot interventie bij financiële ondernemingen in problemen (Wet bijzondere maatregelen financiële ondernemingen), Stb. 2012, 241. The Act came into force with retroactive effect from 20 January 2012. Unlike the bank resolution measures under the BRRD and SRM Regulation and expropriation under Section 6:2 Wft, the application of the transfer regime by DNB under Part $3 \mathrm{Wft}$ was subject to court approval.

Curiously enough, a closer look at the Explanatory Notes to the draft Intervention Act reveals that the powers were merely presented in the context of banking supervision. The parliamentary history did not devote much attention to the interaction of the measures with insolvency law. The intervention powers were granted to DNB in its capacity as supervisory authority as an additional set of supervisory powers and the legislative history does not explicitly indicate that principles such as that creditors must be treated in an equitable manner or shareholders must bear first losses were applicable. Cf. Kamerstukken II 2011/12, 33059, no. 3.

See Decree by the Minister of Finance of 1 February 2013 regarding the expropriation of securities and assets of SNS REAAL NV and SNS Bank NV in connection with the stability of the financial system, and to take immediate measures with regard to SNS REAAL NV. Available at www.government.nl. On the Dutch Minister of Finance's offer for compensation of March 2013, see www.government.nl. case of SNS Reaal', Journal of International Banking Law and Regulation (2016), p. 162 166. 2014, p. 29-32; Hoeblal \& Wiercx 2013, supra n. 66, p. 269. On the nationalisation of SNS Reaal in 2013 and the comparison with bail-in, see B. Bierens, 'Over het besluit tot nationalisatie van SNS Reaal en de rechtelijke toetsing daarvan: terugkijken en vooruitblikken', Tijdschrift voor Financieel Recht (2013) no. 4, p. 112; Hoeblal \& Wiercx 2013, supra n. 66, p. 275-276. In contrast to DNB's transfer powers under Part $3 \mathrm{Wft}$, the expropriation tool under Section 6:2 Wft continues to exist alongside the 
bank resolution framework of Part 3a Wft and the SRM Regulation. According to the legislative history of Part 3a Wft, the expropriation tool under Article 6:2 Wft should be considered emergency power legislation. See Janssen \& Tegelaar 2016, supra n. 176, p. 165; Kamerstukken II 2014/15, 34 208, nr. 3, p. 51. According to Drijber and Van Toor the possibility for national authorities to nationalize a bank has been limited substantially and Member States are not allowed to circumvent the resolution measures of the Single Resolution Board through nationalization but the Dutch expropriation tool may be of relevance if the Single Resolution Board fails to take the necessary decisions or the Single Resolution Fund is empty. See B.J. Drijber \& A. van Toor, 'Van ESA's, SSM en SRM: rechtsbescherming in een labyrint van Europese regels voor het financiële toezicht', Ondernemingsrecht 2015, p. 13-25.

See Schillig 2016, supra n. 8, p. 295-296, who also discusses that the meaning of the provisions in not entirely clear. Interestingly enough, Section 3a:25 Wft, which transposes Article 53(3) and (4) BRRD into Dutch law, does not use the phrase 'for all purposes'.

179

180

181

182

183

184

185

186

187

188

189

190

191

192

193

194

195 Cf. Sections 7:850(1), 855(1) BW.

See Schillig 2016, supra n. 8, p. 295.

See Kamerstukken II 2014/15, 34 208, nr. 3, p. 93-94.

Cf. Kamerstukken II 2014/15, 34 208, nr. 3, p. 93-94.

See Schillig 2016, supra n. 8, p. 295; Sommer 2014, supra n. 68, p. 219-220.

See Schillig 2016, supra n. 8, p. 295-296.

Cf. Schillig 2016, supra n. 8, p. 296.

See Thole 2016, supra n. 22, p. 63; Schelo 2015, supra n. 117, p. 135.

See Article 48(1) BRRD; Article 17(1) SRM Regulation; Thole 2016, supra n. 22, p. 63; Schelo 2015, supra n. 117, p. 135.

Thole 2016, supra n. 22, p. 63; Schelo 2015, supra n. 117, p. 135. Cf. Article 34(1)(a) BRRD; Article 15(1)(a) SRM Regulation. Schelo 2015, supra n. 117, p. 135-136 notes that in some cases only a debt write-down may be considered, for instance if the bank is state-owned and there is no equity that can be given to the creditors.

Schelo, supra n. 117, p. 136.

Cf. Article 63(2) BRRD. Section 3a:6 Wft provides that the procedural requirements in Article 81, 83 BRRD do apply, the measures in the phase of resolution planning are exempted from the restrictions in Section 3a:6 Wft and if the sale of business tool is applied, the private sector purchaser needs to agree with the sale. See Kamerstukken II 2014/15, 34 208, nr. 3, p. 80-82.

See Kamerstukken II 2014/15, 34 208, nr. 3, p. 81.

According to the prevailing view in Dutch legal literature a claim can be converted into equity through the assignment of the claim to the company on the one hand, which results in an automatic extinction of the shareholder's payment obligation as creditor and shareholder become the same legal person, or set-off by the company of the creditor's claim against the capital contribution obligation on the other hand. See e.g. Tollenaar 2008, supra n. 77, p. 79; M.J.C. Arends, 'Kwalificatie van omzetting van een vordering in aandelenkapitaal', Vennootschap \& Onderneming (2006) no. 6, p. 165; M. Olaerts \& J.J.A. Hamers, 'Van schuldeiser tot kapitaalverschaffer: meerdere wegen leiden naar Rome', Tijdschrift Stichting Vereniging en Vennootschap (2003), p. 145; Schutte-Veenstra 1991, supra n. 55, p. 32.

Cf. Thole 2016, supra n. 22, p. 63; Schelo 2015, supra n. 117, p. 136, who note that national private law will guide the formalities of the conversion and set out how the conversion looks like under German law.

Cf. S. Engelbach \& T. Friedrich, 'Die Umsetzung der BRRD in Deutschland', WM Zeitschrift für Wirtschafts- und Bankrecht (2015), p. 667; Thole 2016, supra n. 22, p. 63. See Schelo 2015, supra n. 117, p. 136. 
Gesetzentwurf der Bundesregierung, BRRD-Umsetzungsgesetz, Deutscher Bundestag, Drucksache 18/2575, 22 September 2014, p. 175.

See Schelo 2015, supra n. 117, p. 136. See also Cahn \& Kenadjian 2014, supra n. 57, p. 52. See e.g. G. van Solinge \& M.P. Nieuwe Weme, Mr. C. Assers Handleiding tot de beoefening van het Nederlands Burgerlijk Recht. 2. Rechtspersonenrecht. Deel IIa. NV en BV-Oprichting, vermogen en aandelen, Deventer: Kluwer 2013, para. 128; E.J.J. van der Heijden \& W.C.L. van der Grinten, Handboek voor de naamloze en de besloten vennootschap, Deventer: Kluwer 2013, p. 236-237; Tollenaar 2008, supra n. 77, p. 7981; Arends 2006, supra n. 192, p. 165-168. Contra J.B.W.M. Kemperink, Vraagstukken rond (terug) storting op NVIBV aandelen en van coöperatierecht, Deventer: Kluwer 2006, p. 73-104; Olaerts \& Hamers 2003, supra n. 192, p. 140-153.

See Tollenaar 2008, supra n. 77, p. 79-81; Arends 2006, supra n. 192, p. 167; Kemperink 2006, supra n. 198, p. 73-104; Olaerts \& Hamers 2003, supra n. 192, p. 149-151. Cf. Schelo 2015 , supra n. 117, p. 136, who notes that for a debt to equity swap under German law, the 'real' value rather than the nominal value of a claim is the relevant value.

Article 36(1) BRRD; Article 20(1) SRM Regulation.

European Banking Authority, Consultation Paper, Draft Regulatory Technical Standards on valuation under Directive 2014/59/EU, EBA/CP/2014/38. Cf. Schelo 2015, supra $\mathrm{n} .117$, p. 136-138. It is worth nothing that these valuations to inform the resolution decisions should be distinguished from the valuations required under the ncwo principle, which exist of a determination of the treatment of shareholders and creditors in a hypothetical liquidation procedure, of a determination of the proceeds received in a resolution procedure and of a comparison between these two outcomes. See paragraph 4.1.1; Article 74 BRRD; Section 3a:20 Wft.

See Schelo 2015, supra n. 117, p. 136-137.

European Banking Authority, Consultation Paper, Draft Guidelines on the rate of conversion of debt to equity in bail-in, EBA/CP/2014/39.

See European Banking Authority, Consultation Paper, Draft Guidelines on the rate of conversion of debt to equity in bail-in, EBA/CP/2014/39, p. 11; T.F. Huertas, 'Resolution Requires Reform', in: P.S. Kenadjian (ed.), Too Big To Fail - Brauchen wir ein Sonderinsolvenzrecht für Banken?, Berlin/Boston: Walter de Gruyter 2012, p. 81.

European Banking Authority, Consultation Paper, Draft Regulatory Technical Standards on valuation under Directive 2014/59/EU, EBA/CP/2014/38.

Sections 153(2) and 272(2) Fw. See Hummelen 2016, supra n. 79, p. 77; Wessels 2014, supra n. 132, para. 8397a; Wessels 2013, supra n. 140, para. 6116.

See for an overview, Hummelen 2016, supra n. 79, p. 69-119.

L.A. Bebchuk, 'Using options to divide value in corporate bankruptcy', European Economic Review 44 (2000), p. 829-843; L.A. Bebchuk, 'A new approach to corporate reorganizations', Harvard Law Review 101 (1988), p. 775-804. Amendments to Bebchuk's model were proposed by $\mathrm{Ph}$. Aghion et al., 'The economics of bankruptcy reform', The Journal of Law, Economics, and Organization 8 (1992), p. 523-546. See also Eidenmüller 2016, supra n. 41, p. 25; R. Bork, Rescuing companies in England and Germany, Oxford: Oxford University Press 2012, para. 15.21; A. Dilger, 'Forced to make mistakes: reasons for complaining about Bebchuk's scheme and other market oriented insolvency procedures', European Journal of Law and Economics 21 (2006), p. 79-94. See Bebchuk 2000, supra n. 208, p. 833-838; Bebchuk 1988, supra n. 208, p. 785-788. See Bebchuk 2000, supra n. 208, p. 839-840; Aghion et al. 1992, supra n. 208, p. 539-540. See also Hummelen 2016, supra n. 79, p. 109-119.

M.J. Roe, 'Bankruptcy and Debt: A New Model for Corporate Reorganization', Columbia Law Review 83 (1983), p. 527-602.

De Nederlandsche Bank 2016, supra n. 31, p. 9.

Cf. De Nederlandsche Bank 2016, supra n. 31, p. 8, 10. On the implementation of bailin, see also Kamerstukken II 2014/15, 34 208, nr. 3, p. 22-23 and 92. Cf. also Coffee 2010, 
supra n. 61, p. 35: '[...] if the debt security converts into common stock, the newly issued common stock would predictably come to be owned by the same categories of institutional investors as already held that common stock. Little would change. This is both because some debt investors (for example, money market funds) cannot legally hold common stock and, more generally, because the holders of debt securities tend to be risk averse (or at least want to maintain their prior portfolio balance and so, after conversion, will replace the former debt security that they held with a new debt security by selling the common stock that they receive).'

Although under the ISDA Master Agreement, which is the widely used agreement for over-the-counter derivative transactions, market based methods are used to determine the net amount on the early termination of derivative transactions.

Annex to Kamerstukken II 2014/15, 34 208, no. 5, p. 7 (Comments to the proposal for the Implementation Act European framework for recovery and resolution of banks and investment firms of G.W. Kastelein \& V.P.G. de Serière, 23 June 2015).

216 See De Serière 2014, supra n. 145, p. 166-167.

See Ph. Wood, 'The Bankruptcy Ladder of Priorities', Business Law International 14 (2013), p. 212-213.

See McCormack et al. 2016, supra n. 150, p. 126-129; J.W. Westbrook et al., A global view of business insolvency systems, Washington DC: The World Bank 2010, p. 183-201. De Serière 2014, supra n. 145, p. 166-167; Mucciarelli 2013, supra n. 41, p. 179-180; J.M. Garrido, 'The distributional question in insolvency: Comparative aspects', International Insolvency Review 4 (1995), p. 25-53. For an extensive and recent analysis of the ranking of claims and order of priorities in EU Member States, see McCormack et al. 2016, supra n. 150 , p. $112-136$. Cf. Article 48(1) BRRD.

See Bliesener 2013, supra n. 45, p. 199.

De Serière 2014, supra n. 145, p. 166-167.

Bliesener 2013, supra n. 45, p. 199.

On a so-called 'carve-out approach' and a 'waterfall approach' to determine which classes of liabilities should fall within the scope of the bail-in mechanism, see Huertas 2013, supra n. 27, p. 172-173.

See J.A. Chan-Lau \& H. Oura, 'Bail-in power, depositor preference, and asset encumbrance: the end of cheap senior unsecured debt? A structural pricing perspective', 2016, available at ssrn.com., p. 21. According to Wojcik 2016, supra n. 39, p. 123 the exclusion of liabilities from bail-in will effectively result in a 'juniorization' of other liabilities.

Cf. Article 48(1) BRRD and Article 17(1) SRM Regulation. Recital 77 BRRD notes that '[e]xcept where otherwise specified in this Directive, resolution authorities should apply the bail-in tool in a way that respects the pari passu treatment of creditors and the statutory ranking of claims under the applicable insolvency law.'

$C f$. De Serière 2014, supra n. 145, p. 166-167, who discusses the 'investor only bailin approach' in which losses are imposed on the investors who fund the use of the infrastructural functions of a bank, such as bondholders, and not on customers who use these functions. See also Gleeson \& Guynn 2016, supra n. 18, p. 5-6.

$C f$. B. Reynolds \& E. Teo, 'Early Bank Recovery and Resolution Directive (BRRD) experiences: lessons learned from Greece', Journal of International Banking Law and Regulation 31 (2016), p. 360-361.

$C f$. the discussion of the resolution principles in paragraph 4.1.2.

Article 48(2)(a) BRRD; Article 27(3)(a) SRM Regulation.

Article 2(1)(67) BRRD defines 'secured liability' as '[...] a liability where the right of the creditor to payment or other form of performance is secured by a charge, pledge or lien, or collateral arrangements including liabilities arising from repurchase transactions and other title transfer collateral arrangements.' Moreover, under Article 44(2) BRRD and 
Article 27(3) SRM Regulation excluded secured liabilities include '[...] covered bonds and liabilities in the form of financial instruments used for hedging purposes which form an integral part of the cover pool and which according to national law are secured in a way similar to covered bonds.' Yet, the part of a secured liability or a liability for which collateral has been pledged that exceeds the value of the assets, pledge, lien or collateral against which it is secured, falls within the scope of the bail-in mechanism.

Article 48(2) BRRD; Article 27(3) SRM Regulation. Liabilities to tax and social security authorities are only excluded if they have a preferential position under national law.

Article 44(2)-(3) BRRD; Article 27(5)-(6) SRM Regulation. $C f$. Article 33(2) BRRD and Article 14(2) SRM Regulation, which list five resolution objectives, such as ensuring the continuity of critical functions and the protection of depositors. On the discretionary exclusion of liabilities from bail-in, see Gardella 2015, supra n. 67, p. 394-396; Tröger 2015, supra n. 67. See also Franke et al. 2014, supra n. 111, p. 564 and Adolff \& Eschwey 2013, supra n. 43, p. 964, who argue against such a power for resolution authorities. Article 44(2)-(3) BRRD; Article 27(5)-(6) SRM Regulation. See also Article 3 Commission Delegated Regulation (EU) 2016/1450 of 23 May 2016 supplementing Directive 2014/59/EU of the European Parliament and of the Council with regard to regulatory technical standards specifying the criteria relating to the methodology for setting the minimum requirement for own funds and eligible liabilities (OJ L 237, 3.9.2016, p. 1).

For a discussion of the hierarchy of claims in bail-in under the German Recovery and Resolution Act (Sanierungs- und Abwicklungsgesetz), which implements the BRRD in Germany, and a comparison with the ranking of claims under the German Insolvency Act (Insolvenzordnung), see D. Skauradszun \& B. Herz, 'Die Haftungskaskade bei der Bankenabwicklung nach dem SAG und deren Verzahnung mit dem (Banken-) Insolvenzrecht', Deutsche Zeitschrift für Wirtschafts- und Insolvenzrecht (2016), p. 501509.

For a discussion of all types of insolvency and administration claims under Dutch law, see D. Faber \& N. Vermunt, 'National report for the Netherlands', in: D. Faber et al. (eds.), Ranking and priority of creditors, Oxford: Oxford University Press 2016, p. 337378.

See Wessels 2016, supra n. 25, para. 1006-1007.

Sections 3:283-289 BW distinguish between specific privileges and general privileges. Sections 3:290-291 BW.

Section 57(1) Fw; Sections 3:278, 3:288(c)-(e) BW; Section 21 Tax Collection Act 1990 (Invorderingswet). For a discussion of the priorities based on security rights, preferential rights and other statutory grounds, see F.M.J. Verstijlen, 'Paritas creditorum, voorrang en preferentie', Tijdschrift voor Privaatrecht 43 (2006) no. 2, p. 1157-1228; W.P. Erasmus, Bevoorrechte vorderingen: Preferenties naar geldend en wordend recht, Zwolle: Tjeenk Willink 1976.

A.M.J. van Buchem-Spapens \& Th. A. Pouw, Faillissement, surseance van betaling en schuldsanering, Deventer: Kluwer 2013, p. 62. The Fw does not define 'boedelschulden', the exact meaning derives from case law.

For a discussion of the administration claims (boedelvorderingen), see e.g. A.I.M. van Mierlo, 'Boedelschulden. Mag het ietsje minder zijn?', Tijdschrift voor Insolventierecht (2004); F.M.J. Verstijlen, De faillissementscurator, Deventer: W.E.J. Tjeenk Willink 1998, p. 165-189.

Section 53 Fw. See Verstijlen 2006, supra n. 240, p. 1219-1220.

Erasmus 1976, supra n. 240, p. 37, 56-79.

See B. Wessels, 'Moeten schuldeisers altijd gelijk behandeld worden?', Nederlands juristenblad 85 (2010); Verstijlen 2006, supra n. 240, p. 1161.

See e.g. Hummelen 2016, supra n. 79, p. 16-17; Wessels 2010, supra n. 245; J.C. van Apeldoorn, 'De paritas creditorum is dood, leve de paritas creditorum', in: N.E.D. 
Faber, Bancaire zekerheid. Liber amicorum mr. J.H.S.G.K. Timmermans, Deventer: Kluwer 2010, p. 25-42; R.D. Vriesendorp, 'Zeker een goed verhaal. Contouren van een nieuw preferentiestelsel', in: J.C. van Apeldoorn, Onzekere zekerheid, Deventer: Kluwer 2001, p. 3-11.

See A. Mennens, 'Over het verdelen van de taart in faillissement door middel van carveout regelingen, Tijdschrift voor Insolventierecht 19 (2013); Van Mierlo 2004, supra n. 242. Faber \& Vermunt 2016, supra n. 236, para. 12.03.

Hadjiemmanuil 2015, supra n. 72, p. 242. Cf. Thole 2012, supra n. 22, p. 223, who argues that the par conditio creditorum principle should not be marginalised too easily by the German bank insolvency rules.

Cf. International Monetary Fund, Cross-border bank resolution: recent developments, June 2014, p. 14; Bliesener 2013, supra n. 45, p. 199.

Cf. Binder 2015, supra n. 6, p. 10; Thole 2012, supra n. 22, p. 19-20.

See Wojcik 2016, supra n. 39, p. 125.

Binder 2015, supra n. 6, p. 9.

Wojcik 2016, supra n. 39, p. 123; M. Schillig, 'The EU resolution toolbox' in: M. Haentjens \& B. Wessels (eds.), Research Handbook on Crisis Management in the Banking Sector, Cheltenham/Northampton: Edward Elgar Publishing 2015, p. 97 . Cf. Recital 111 BRRD.

Article 108 BRRD provides that deposits from natural persons, micro, small and medium-sized enterprises that would be eligible for coverage by a deposit guarantee scheme were they not made through branches located outside the EU of institutions established within the EU also have a priority status.

Schillig 2016, supra n. 8, p. 366-367. Cf. Reynolds \& Teo 2016, supra n. 228, p. 361.

Cf. Recital 111 BRRD.

Kamerstukken II 2014/15, 34 208, nr. 3, p. 128.

Cf. Title 10 Book 3 BW.

See Wessels 2010, supra n. 245; Verstijlen 2006, supra n. 240, p. 1161.

In addition to the preferential status granted to depositors and deposit guarantee schemes under Article 108 BRRD, under Article 37(7) BRRD resolution authorities and financing arrangements can be granted preferential status regarding the expenses they incur in connection with the use of the resolution tools and powers. According to Schillig 2016, supra n. 8, p. 366 this is an administrative expense priority.

Valiante 2016, supra n. 39, p. 23-25. See also Schillig 2016, supra n. 8, p. 366; Summary Report of the $27^{\text {th }}$ Meeting of the Commission Expert Group on Banking, Payments and Insurance, 17 June 2015, available at ec.europa.eu; International Monetary Fund 2014, supra n. 250, p. 13-15. But see Deutsche Bundesbank 2014, supra n. 115, p. 40 which seems to refer incorrectly to a large part of a bank's liabilities being subject to 'harmonised insolvency legislation'.

Wojcik 2016, supra n. 39, p. 124-126, 130-131; International Monetary Fund 2014, supra n. 250, p. 14. See also P.M. Wiórek, Das Prinzip der Gläubigergleichbehandlung im Europäischen Insolvenzrecht, Baden-Baden: Nomos Verlagsgesellschaft 2005, p. 99195 , providing an extensive comparative analysis of general insolvency laws of several Member States, and Garrido 1995, supra n. 219, p. 31, 39-52, providing a general analysis of priorities under insolvency law. See also Eidenmüller 2016, supra n. 41, p. 16-19; Wood 2013, supra n. 217.

Wojcik 2016, supra n. 39, p. 125-126. Article 10 Winding-up Directive provides that the ranking of claims in an insolvency procedure is one of the aspects that is subject to the determination of the law of the bank's home Member State. As noted by Wojcik 2016, supra n. 39, p. 125, under the Winding-up Directive insolvency laws of other Member States may be applicable to other aspects of the procedure. 
Cf. Article 44(2)(g)(iii) BRRD; Kamerstukken II 2015/16, 34 208, nr. E; Section 3:278(1) BW; Section 21 Tax Collection Act 1990 (Invorderingswet).

Bliesener 2013, supra n. 45, p. 207-208.

Schillig 2015, supra n. 254, p. 96-97; Avgouleas 2012, supra n. 61, p. 417. See also Ch. Thole, 'Bank Crisis Management and Resolution, Core features of the Bank Recovery and Resolution Directive', 2014, available at ssrn.com, p. 19-20. According to Avgouleas 2012, supra n. 61, p. 417 ' ' a a]lthough equity holders should be wiped out and subordinated debt should be written down completely before senior debt holders bear any losses, it is doubtless that the pari passu principle shall be violated. It is inevitable that certain classes of debt linked to swap, repo and derivatives counterparties and other trade creditors, retail and wholesale depositors, and secured debt holders would be excluded from the write down. Netting arrangements under master agreements should also be excluded from the ambit of the write down power.'

Wojcik 2016, supra n. 39, p. 123; Huertas 2013, supra n. 27, p. 172-173.

Schillig 2015, supra n. 254, p. 98.

Proposal for a Directive of the European Parliament and of the Council on amending Directive 2014/59/EU of the European Parliament and of the Council as regards the ranking of unsecured debt instruments in insolvency hierarchy (COM (2016) 853 final, 23.11.2016).

Proposal for a Directive of the European Parliament and of the Council on amending Directive 2014/59/EU of the European Parliament and of the Council as regards the ranking of unsecured debt instruments in insolvency hierarchy (COM (2016) 853 final, 23.11.2016); Article 45b(3) Proposal for a Directive of the European Parliament and of the Council amending Directive 2014/59/EU on loss-absorbing and recapitalisation capacity of credit institutions and investment firms and amending Directive 98/26/EC, Directive 2002/47/EC, Directive 2012/30/EU, Directive 2011/35/EU, Directive 2005/56/ EC, Directive 2004/25/EC and Directive 2007/36/EC (COM(2016) 852 final, 23.11.2016). Besides facilitating the exercise of bail-in, especially in the context of the ncwoprinciple, the proposed provisions aim to implement the international standards on Total Loss Absorbing Capacity of the Financial Stability Board, which standard is also implemented via amendments to CRR. Moreover, the proposal follows developments on statutory subordination of certain types of claims in several Member States. see Valiante 2016, supra n. 39, p. 22-23.

Valiante 2016, supra n. 39, p. 31-32, who notes that '[t] he full harmonisation approach of insolvency regimes would foster rapid convergence across Euro area countries, but would not necessarily address clashes with local laws that also reflect the existence of those differences in insolvency laws in the first place. [...] the full harmonisation approach is a concrete solution in very specific areas, like the ranking of creditors, due to the benefits that such harmonisation would create for the single market and for the stability of the financial system (in resolution actions). This is currently the preferable tool for the proposal on the harmonisation of ranking of creditors under the BRRD.'

Mucciarelli 2013, supra n. 41, p. 197-199. Cf. McCormack et al. 2016, supra n. 150, p. 135-136, who raise in their chapter on the ranking of claims and order of priorities in EU Member States '[...] a number of issues that are appropriate for consideration by the European legislator although some om them may be rather controversial and it may be difficult to secure agreement.'

See Eidenmuller 2016, supra n. 41, p. 16; Mucciarelli 2013, supra n. 41, p. 197; Garrido 1995 , supra n. 219, p. $27-53$.

Mucciarelli 2013, supra n. 41, p. 199.

The European Commission considered several options, including statutory subordination of unsecured debt with retroactive effect. See Proposal for a Directive of the European Parliament and of the Council on amending Directive 2014/59/EU of the European Parliament and of the Council as regards the ranking of unsecured 
debt instruments in insolvency hierarchy (COM (2016) 853 final, 23.11.2016) and

$C f$. J.A. Kirshner, 'The bankruptcy safe harbor in light of government bailouts: reifying the significance of bankruptcy as backstop to financial risk', Journal of Legislation \& Public Policy 18 (2015), p. 827-834; Baird \& Morrison 2011, supra n. 22, p. 287-289. 